No. 19-7

\title{
How Does Liquidity Affect Consumer Payment Choice?
}

\section{Joanna Stavins}

\begin{abstract}
:
We measure consumers' readiness to face emergency expenses. Based on data from a representative survey of US consumers, we find that financial readiness varies widely across consumers, with lowest-income, least-educated, unemployed, and black consumers most likely to have $\$ 0$ saved for emergency expenses. For these consumers, even a temporary financial shock, either an unexpected negative income shock (such as a layoff or a short-term government shutdown) or an unexpected expenditure (such as a medical expense or a car repair), could have severe financial consequences. The literature likely underestimates the consequences, because consumers who are not financially prepared to cover unexpected expenses are more likely to borrow on their credit cards, adding to their existing debt. Thus the cost of relying on credit cards is likely very high for consumers who are already financially vulnerable. We use panel data to examine whether consumers who experienced a substantial drop in income from one year to the next, like one resulting from a layoff or a government shutdown, increased their credit card borrowing. We do not find evidence that a negative income shock raises consumers' likelihood of revolving on credit cards or increasing the amount borrowed.
\end{abstract}

\section{JEL Classifications: D12, D14, D15, E21}

Keywords: emergency savings, credit card debt, unexpected expenses

Joanna Stavins is a senior economist and policy advisor in the research department at the Federal Reserve Bank of Boston. Her email is \oanna.Stavins@bos.frb.org.

The author is grateful to José Fillat and Joe Peek for helpful comments, Liang Zhang for excellent research assistance, and Larry Bean for diligent editing.

This paper presents preliminary analysis and results intended to stimulate discussion and critical comment. The views expressed herein are those of the author and do not indicate concurrence by the Federal Reserve Bank of Boston, the principals of the Board of Governors, or the Federal Reserve System.

This paper, which may be revised, is available on the website of the Federal Reserve Bank of Boston at http://www.bostonfed.org/economic/wp/index.htm.

This version: August 2019

https://doi.org/10.29412/res.wp.2019.07 


\section{Introduction}

During the 2018-2019 US government shutdown, approximately 800,000 federal employees plus many contractors working for the government did not receive their regular paychecks.

Presumably, many of these people relied on their savings to cover their everyday expenses and pay their bills, or - alternatively - they relied on expensive credit, incurred late-payment fees, or missed payments entirely and adversely affected their credit ratings. Using a recent representative survey of US consumers (conducted before the government shutdown), we show that 25 percent of consumers have not saved any money for emergencies. If faced with an unexpected expense of $\$ 2,000$, nearly half of the respondents said they would not be able to cover it within a month. However, many of the respondents who would be able to cover the expense within a month said that to do so, they would have to rely on costly sources of funds, such as credit cards, overdrafts, or payday loans.

Emergency savings is an important topic in the literature on consumer financial decisionmaking, but a link to payment choice is missing. We add to the discussion by analyzing how consumers' emergency savings, or lack thereof, relate to their payment behavior. In particular, we focus on credit card use and borrowing by consumers who have little or no emergency savings, people who are sometimes characterized as financially fragile. We find that those who lack sufficient liquid assets to cover emergency expenses or negative income shocks are much more likely to revolve their credit card debt - that is, to carry a balance from one month to the next - which can result in costly fees and interest payments. Because the literature on emergency savings does not address credit card use and its associated costs, it likely underestimates the financial effect of unexpected shocks.

The financial industry typically recommends that consumers have enough liquid savings to cover at least three to six months' worth of expenses. ${ }^{1}$ In 2016 , the median household annual income was $\$ 60,309$ (US Census), and so three months' worth of the median income amounts to slightly more than $\$ 15,000$. Therefore, even after taxes are subtracted, a median household should have several thousand dollars in liquid savings, assuming that expenses are roughly equal

\footnotetext{
${ }^{1}$ See, for example, https://investor.vanguard.com/emergency-fund/ or https://www.wellsfargo.com/financialeducation/basic-finances/manage-money/chflow-savings/emergencies/.
} 
to income. However, the data show that the majority of US households are not prepared to handle financial emergencies. The 2018 Survey of Household Economics Decisionmaking $(\mathrm{SHED})^{2}$ finds that only 60 percent of Americans could cover an unexpected $\$ 400$ expense using cash or its equivalent, while the rest either would have to borrow money or sell a possession or could not finance the expense at all (Board of Governors 2019). These estimates from SHED on how so few families could pay a $\$ 400$ emergency expense out of liquid savings have garnered considerable attention (see Gabler 2016, for example), because they raise serious concerns about the financial vulnerability of US households.

Analyzing payment behavior provides more insight into the financial situation of US households. The literature likely underestimates the financial consequences of a lack of readiness, because, as noted above, consumers who are not financially prepared to cover unexpected expenses or negative income shocks tend to borrow on their credit cards and add to their existing debt. We use panel data to examine whether consumers who experienced a substantial drop in income from one year to the next, similar to one that could result from a government shutdown, increased their credit card borrowing. We do not find evidence that a negative income shock raises consumers' likelihood of revolving on credit cards or increasing the amount borrowed.

The rest of this paper is organized as follows. Section 2 summarizes the literature on emergency savings. Section 3 describes the data used in this study. Section 4 shows how the amount of emergency savings varies across consumers. Section 5 presents the regression models we use to isolate the effects of consumers' attributes on their financial readiness. Section 6 shows how credit card use and revolving relate to consumers' financial readiness. Section 7 uses panel data to test whether negative income shocks lead to borrowing on credit cards. Section 8 concludes.

2 The SHED survey has been conducted by the Board of Governors of the Federal Reserve annually since 2013 . See https://www.federalreserve.gov/consumerscommunities/shed.htm. 


\section{Literature review}

Other studies show a picture of US households' financial readiness that is as bleak as the one presented by the SHED survey, although the exact measures of financial readiness vary across studies. A 2018 Bankrate.com survey of 1,000 US adults found that only 18 percent had enough savings to cover three to five months' worth of expenses, and that only 29 percent had sufficient savings to last more than six months. So, only 47 percent of US adults were deemed financially prepared for emergency expenses, with only 39 percent able to cover a $\$ 1,000$ emergency with their savings without borrowing. ${ }^{3}$

In related work, Lusardi, Schneider, and Tufano (2011) find that nearly half of US families say they probably could not manage a $\$ 2,000$ emergency expense. However, using the Survey of Consumer Finance (SCF) data, Pence (2011) finds that a much smaller fraction of families could not cope with a $\$ 2,000$ expense shock. Also using the SCF, Bhutta and Dettling (2018) estimate that 24 percent of families have less than $\$ 400$ in liquid savings. Only 40 percent of families have liquid savings equivalent to at least three months of expenses, and fewer than 30 percent have liquid savings equivalent to at least six months of expenses. Older, higher-income, and married families tend to have more liquid savings, but even many of those families do not have more than three months' worth of expenses in liquid assets. Babiarz and Robb (2014) find that consumers with a higher degree of financial literacy are more likely to have emergency savings. Based on the SCF data, Kennickell and Lusardi (2004) find that older people are more likely to have emergency savings.

Gelman et al. (2018, updated in 2019) use the experience of the 2013 government shutdown to show that a large majority of government workers did not have enough money in the bank to cover expenses for two weeks. ${ }^{4}$ Baker and Yannelis (2017) examine the effect of the 2013 government shutdown and find that consumption is highly sensitive to even a temporary income shock. More generally, Baker (2018) finds that the elasticity of consumption with respect to income is significantly higher among households with higher levels of debt. However, because the various studies use different measures of financial preparedness, it is typically difficult to

\footnotetext{
${ }^{3}$ See https://www.bankrate.com/banking/savings/financial-security-june-2018/.

${ }^{4}$ See https://www.nytimes.com/2019/01/16/opinion/shutdown-federal-workers-trump.html.
} 
compare their findings. This paper contributes to the literature by analyzing a relationship between consumers' amount of emergency savings and their payment behavior.

\section{Data}

We use data from the 2017 Diary of Consumer Payment Choice (DCPC), a representative survey of US adults conducted by the Federal Reserve Banks of Atlanta, Boston, Richmond, and San Francisco. The DCPC is a three-day diary survey of consumer payment behavior conducted in October to complement the annual Survey of Consumer Payment Choice (SCPC). The SCPC, also conducted by the Federal Reserve, collects data on payment instruments adoption and use from a representative sample of US adults. It also collects consumers' assessments of characteristics of major payment instruments. Moreover, the SCPC gathers detailed information about the respondents' bank account holdings and cash and card holdings, as well as demographic and income data. The SCPC and the DCPC collect data from the same set of respondents. Appendix Table 1 shows the use of payment instruments by demographic and income cohorts, based on the 2017 SCPC.

The 2017 DCPC includes responses with detailed transaction-level data from 2,793 adults. Each respondent filled out the diary for a specified three consecutive days. For each transaction conducted during the three-day period, respondents recorded the dollar value, type of merchant, type of transaction, and the payment instrument used. Transactions included all retail purchases conducted in person and online, bill payments, and person-to-person payments. ${ }^{5}$

In addition to collecting transaction data, the survey asked respondents about their emergency savings. Each respondent was asked the following questions:

Question 1: As of today, how much money do you have saved for emergency expenses?

Question 2: Assume that you were facing an emergency expense of $\$ 2,000$ that could not be avoided. You would need to make this $\$ 2,000$ payment within one month. Examples: your car breaks down and you need it to get to work; pipes burst in your house, and plumbing must be immediately repaired. How much of this $\$ 2,000$ could you pay within one month (the next 30 days)?

\footnotetext{
${ }^{5}$ For more details on the 2017 DCPC, see Greene and Stavins (2018).
} 
Each question yielded a very high response rate. Of the DCPC's 2,793 participants, 2,775 reported their total emergency savings, and 2,783 reported how much of a $\$ 2,000$ emergency expense they could cover in a month.

For Question 1, survey participants were also asked to provide the sources of the money they had saved and the total amount they had saved. The sources of emergency funds included cash, checking account, savings account, and prepaid card. Table 1 summarizes the average total amount saved for emergency expenses and the average total by source of funds. About 25 percent of the respondents indicated that they did not have any emergency savings $(\$ 0)$. The mean total amount of savings was $\$ 11,724$. That amount is much larger than what other surveys have found, but the question did not instruct the respondents to exclude their retirement funds or any other illiquid savings.

Unlike Question 1, Question 2 allowed respondents to include sources of funding beyond their own savings, such as borrowing from family or friends, or charging on a credit card. Moreover, because the survey participants were asked how much money they could come up with over the period of one month, they did not necessarily have to have the declared amount readily available.

Table 2 shows a breakdown of funds toward a $\$ 2,000$ expense by source. The top row shows the percentage of all consumers who would use each of the sources to fund at least a portion of a $\$ 2,000$ emergency expense (extensive margin). The second row shows the average amount that would be drawn from each source by those consumers who would use it (intensive margin). Many consumers would have to rely on costly sources of money to cover at least some of the emergency expense. For example, 17.5 percent would rely on credit cards to come up with some or all of their emergency funds. Among those who would use credit cards, the average amount borrowed would be $\$ 1,275$. In 2017 , the average annual rate of interest on credit cards carrying balances was 14.4 percent, ${ }^{6}$ so borrowing $\$ 1,275$ would increase a consumer's debt by $\$ 184$ per year, on average. Those consumers who would rely on credit cards are already heavily leveraged and carry substantial credit card debt: the average revolving balance among them is

\footnotetext{
${ }^{6}$ https://www.federalreserve.gov/releases/g19/current/
} 
$\$ 3,779$ (in contrast, the average revolving balance for the rest of the sample is $\$ 1,972$ ). Therefore they would add to their existing costly burden of credit card debt.

About 2 percent of consumers would have to use overdrafts, HELOCs, or payday loans, and almost 13 percent would have to borrow from family or friends. For consumers who would borrow from HELOCs or from their family or friends, the average amount also would be large. The results suggest that a substantial fraction of consumers do not have sufficient savings for unexpected expenses and would have to borrow to cover them, in many cases by using costly sources of funds.

\section{Emergency savings by socio-demographic attributes}

The amount of emergency savings and the amount consumers can come up with toward an unexpected expense vary across consumers. Figures 1 and 2 show how both measures vary geographically across states: Consumers in higher-income states tend to be better financially prepared to face unexpected expenses, on average. We construct a few measures of consumers' readiness to face financial emergencies, based on answers to Questions 1 and 2 above. Table 3 shows the weighted means of five emergency-savings-related measures for the entire sample and by demographic cohort:

1. Average amount of emergency savings that a consumer has

2. Percentage of consumers who have not saved anything for emergency use (have $\$ 0$ )

3. Average amount a consumer can cover in one month if facing a $\$ 2,000$ emergency expense (from $\$ 0$ to $\$ 2,000$ )

4. Percentage of consumers who can cover $\$ 0$ in one month if facing a $\$ 2,000$ emergency expense

5. Percentage of consumers who can cover the full $\$ 2,000$ in one month if facing a $\$ 2,000$ emergency expense

The last column displays the percentage of the total sample in each cohort.

If facing a $\$ 2,000$ emergency expense, the average consumer could come up with $\$ 1,395$ within one month (Table 3, top row). Nearly 7 percent of consumers could not pay any amount toward the $\$ 2,000$ expense ( 6.9 percent can pay $\$ 0$ ). More than half (58.5 percent) of all consumers could come up with the entire $\$ 2,000$. Note that unlike the SHED survey, which 
asked about consumers' current cash holdings, the DCPC asked respondents if they could come up with the funds in a variety of ways, including borrowing on credit cards, taking out a payday loan, or borrowing from a friend or family member. They would have to secure the money within one month, not right away.

Older, more-educated, and higher-income consumers have a greater ability to save for and cover emergency expenses. People with an annual household income of more than $\$ 100,000$ have saved, on average, $\$ 23,388$, and only 0.8 percent of them would be unable to cover any portion (\$0) of a $\$ 2,000$ emergency expense. On average, retirees have saved $\$ 28,161$, more than three times the average amount that employed consumers have saved for emergencies $(\$ 8,965)$. Retired people seem to be better prepared to face emergencies, although non-liquid retirement assets could account for their greater average savings, and those funds might not be accessible on short notice. In addition, using retirement savings to cover emergency expenses before retirement may just delay the potential financial distress until later years.

The lowest-income, least-educated, black, and youngest consumers are significantly more likely to have $\$ 0$ available toward a $\$ 2,000$ emergency expense. In particular, 23 percent of those earning less than $\$ 25,000$ could cover no portion of an emergency expense. The percentage is similar for those who are unemployed. More than half of all consumers (58.5 percent) could cover the entire $\$ 2,000$ emergency expense within a month. But only 20.8 percent of those with an annual income of less than $\$ 25,000$ and only 26.3 percent of those with less than a high school education could cover the full amount. The majority of people in those two cohorts do not even have a credit card they could use for emergency expenses: Only 39 percent of those with income below $\$ 25,000$ and 47 percent of those with less than a high school education have a card. Consumers with less than a high school education ( 7 percent of the sample) seem to be especially vulnerable to an emergency expense: On average, they have only $\$ 858$ in savings. Most of the mean savings for the various demographic cohorts are significantly different from each other.

It is possible that consumers who can rely on a close social network do not need to save as much as those who lack such support, because they can turn to their friends and relatives for financial assistance if faced with an emergency expense. Although we do not have information 
on each person's support system, we use a variable indicating whether a person lives in a rural area as a proxy. This assumes that people living in rural areas are more likely to have a supportive social network than those living in urban areas. We do not find a statistically significant difference between the financial readiness of rural and urban consumers.

\section{a. Do consumers really have enough money to cover an emergency expense?}

We verify whether consumers indeed have funds available to cover as much of an unexpected $\$ 2,000$ expense as they claim they have, in cash or in their checking account. We compare the amount they claim they would get from cash to the amount of cash they report to have stored in their home or elsewhere. Similarly, we compare the amount of money they claim they would get from their checking account to their reported checking account balance.

The results are summarized in Table 4. For 30 percent of consumers, the amount of cash they hold and/or their checking account balance at least equals the amount they claim they could secure from those sources. However, 36 percent of consumers do not have sufficient funds to cover the amount they claim they could raise. Most (71 percent) do not have as much in their checking account as they claim; some accurately report their checking account balance, but their cash holdings are lower than they claim (23 percent). A few people overstate both the amount of their cash holdings and their checking account balance (less than 6 percent). ${ }^{7}$ And even for people whose checking account balance is accurately reported as large enough to cover a $\$ 2,000$ expense, that money might be already designated for other expenses, such as rent, utilities, or car payments. Therefore, even the consumers who claim they have sufficient funds to cover an unexpected emergency expense may not be ready to do so. ${ }^{8}$

\section{b. Government employees}

To assess whether government employees are better prepared to face unexpected financial shocks, such as the recent government shutdown, we compare the respondents who are

\footnotetext{
${ }^{7}$ We could not verify the ability of the remaining consumers to cover a $\$ 2,000$ emergency expense, because they stated that they would rely on additional sources of funding.

${ }^{8}$ To further gauge the reliability of the respondents, we also tested whether respondents who claim not to have sufficient funds might actually report cash and/or checking account holdings greater than $\$ 2,000$, but only 0.37 percent of the sample was found to have such an inconsistency.
} 
government employees with those who are working for a private company, are self-employed, or are not working. There might be self-selection of who works for the government: Government employees might be more risk averse and more likely to be savers, so we could expect them to have more liquid wealth to protect against unexpected shocks. Government employees also might hold higher emergency savings than the average person with low-volatility earnings, reflecting their aversion to risk. On the other hand, self-employed people might have highervolatility earnings, making it more valuable to them to have liquid funds that they can use as a buffer.

Compared with the other sectors, government employees are better at saving for a $\$ 2,000$ emergency expense (Table 5): On average, government employees could come up with \$1,605 of the $\$ 2,000$, compared with the overall sample average of $\$ 1,395$, and 70 percent of government employees could cover the full $\$ 2,000$ within a month. That is the highest share among the employment categories.

Private-company employees do worse than other employment groups at preparing for a financial emergency. Their share of respondents who have not saved anything for an emergency is the highest, and the average amount they could come up with toward covering an unexpected expense is the lowest. The reason why such a relatively small share save for an emergency could be that, even though both government and non-government employees would have to rely on their liquid wealth outside of retirement plans to cover a temporary shortfall in income, in an emergency, a non-government employee might be able to draw from a 401(k) plan, a source that may not be available to government employees or self-employed individuals. Most of the differences between the mean amounts saved by the various employment groups are statistically significant. However, regression results (reported below) indicate that there is no significant effect of being a government employee on the amount of emergency savings, when we control for income, age, and all of the other demographic attributes.

\section{c. Prepared for retirement}

Although everyone should be prepared for financial emergencies, savings are especially important for people who are either retired or near retirement. The amount of savings needed for 
retirement has increased over time, as the average number of years of retirement has increased ${ }^{9}$ and the cost of long-term care has risen. ${ }^{10}$ At the same time, fewer than 25 percent of people in the United States are covered by a defined benefit pension plan. ${ }^{11}$ Retirement might not be included in most people's notion of what constitutes an emergency, but the definition of emergency savings is likely to vary across individuals, and so the amount the survey respondents reported could include retirement savings.

We expect that consumers' savings are highest right before retirement, and then they might decline as people dissave during their retirement. In addition to comparing the savings of retirees with those of people who are working or out of the labor force for other reasons, we compare emergency savings by age. In particular, we test whether those in the late middle-age group (aged 55 to 64) — and therefore likely approaching retirement — have saved more than people in younger age cohorts.

Retirees have significantly higher emergency savings than any other group of consumers and are significantly less likely to have not saved anything (Table 3, columns 1 and 2). They also fare better than other groups in terms of their ability to cover an unexpected $\$ 2,000$ expense: More than 70 percent can cover the full amount. Based on age and without our controlling for employment status, consumers 65 and older have, on average, saved twice as much as consumers aged 45 to 54 or 55 to 64 . In the regression models described below, we control for age and other demographic attributes and test whether retired people are better prepared for emergencies.

\section{d. Emergency savings and income}

Emergency savings increase monotonically with income (Table 3), but do high-income consumers save a greater fraction of their income for emergencies than low-income consumers

\footnotetext{
${ }^{9}$ Life expectancy in the United States has increased since the 1960s, and people retire younger on average. In 2017 , the average life expectancy was 78.54 years (https://data.worldbank.org/indicator/SP.DYN.LE00.IN?locations=US). SHED (Board of Governors 2019) finds that half of retirees in 2017 retired before age 62, and an additional onefourth retired between the ages of 62 and 64 .

${ }^{10}$ According to the US Department of Health and Human Services, on average an American turning 65 today will incur $\$ 138,000$ in future long-term-care costs (https://aspe.hhs.gov/basic-report/long-term-services-and-supportsolder-americans-risks-and-financing-research-brief). The average cost of a private room in a nursing home exceeded $\$ 100,000$ per year in 2018, an increase of 2.9 percent from 2017. (https://www.genworth.com/aging-andyou/finances/cost-of-care.html)

${ }^{11}$ https://www.bls.gov/ncs/ebs/benefits/2018/ownership/civilian/table02a.htm.
} 
do? Table 6 shows the mean ratio of emergency savings to income by demographic and financial cohorts. $^{12}$

The ratio of emergency savings to income increases with age, education, and homeownership, similarly to the way that the absolute amount of emergency savings does. However, the ratio does not increase with income: For all but one income cohort, the ratio of emergency savings to income sits between 0.14 and 0.16 . For robustness, we calculate the ratio of emergency savings to income using actual 2018 household incomes; the 2018 DCPC asks about participants' level of household income, not about income ranges. The results are qualitatively similar: For all but one income cohort, the ratio of emergency savings to income is between 0.12 and 0.16 , and the differences between the income groups' ratios are not statistically significant.

Note that the fraction of households that save nothing for emergencies is much greater among lower-income cohorts, and it decreases with income (Table 3, column 2). Among lowestincome households that save anything for emergencies - more than $\$ 0$ - the proportion of income saved is significantly greater than the proportion saved by higher-income households (Table 6, column 1). These results indicate that lower-income households vary in terms of their approach to emergency savings: Relatively few save for emergencies at all, but those that do save allocate a higher proportion of their income to savings than high-income households do.

These results do not include controls for age or employment, so we cannot determine whether lower-income households that save a relatively large proportion of their income for emergencies are young or old, working or out of work. (We add those controls in the section below). However, we find that the proportion of income saved rises as consumers grow older and, therefore, as they approach retirement; younger people save a very small fraction of their income for emergencies ( 0.03 for those under 25 , the youngest cohort), while older people save a very large fraction ( 0.54 for the those 65 and over, the oldest cohort). Because the emergency savings questions were not added to the DCPC until 2017, we cannot track the flow of

\footnotetext{
${ }^{12}$ The 2017 DCPC data include only ranges of annual household income. We use the midpoint of each cohort as a proxy for the actual income.
} 
emergency savings over time to test whether older people increase their savings faster than younger people do.

\section{Regression models}

In the previous section, we compare average measures of emergency savings among various demographic and employment cohorts. In this section, to examine which consumers are least prepared to handle financial shocks, we estimate the marginal effects of each consumer's attributes on his financial readiness while we control for all other attributes. We estimate the effect of income, employment sector, and demographic variables on consumers' ability to cover emergency expenses, which is measured using four different dependent variables: (1) the amount saved for emergencies $E_{i}$; (2) whether the consumer has saved nothing, or $\$ 0$, for emergencies $E 0_{i} ;(3)$ the amount that the consumer could pay within a month if faced with a $\$ 2,000$ emergency expense $P_{i}$; and (4) whether the consumer could pay nothing, or $\$ 0$, toward a $\$ 2,000$ emergency expense within a month $P 0_{i}$.

$E_{i}=$ amount consumer $i$ has saved for emergencies (in \$)

$E 0_{i}=\left\{\begin{array}{l}1 \text { if consumer } i \text { has saved } \$ 0 \text { for emergencies }\left(E_{i}=0\right) \\ 0 \text { otherwise. }\end{array}\right.$

$P_{i}=$ amount out of a $\$ 2,000$ emergency expense that consumer $i$ could pay within a month (between $\$ 0$ and $\$ 2,000$ )

$P 0_{i}=\left\{\begin{array}{l}1 \text { if consumer } i \text { could pay } \$ 0 \text { within a month }\left(P_{i}=0\right) \\ 0 \text { otherwise }\end{array}\right.$

Although the amount saved for emergencies and the ability to cover an unexpected expense are related, they measure somewhat different concepts. The more a consumer has saved for emergencies, the more likely he is to come up with $\$ 2,000$ on short notice, although the savings, such as retirement funds, might not be liquid. Conversely, a person might not have saved much but could rely on his friends or family, or he might be able to easily borrow on a credit card, albeit at a high interest rate. 
We regress each dependent variable on a set of demographic and financial variables:

$$
Y_{i}=f\left(D E M_{i}, I N C_{i}, E M P_{i}\right)
$$

where

$Y_{i}=\left\{E_{i}, E 0_{i}, P_{i}, P 0_{i}\right\}$ is the set of four dependent variables described above that measure consumer $i$ 's readiness for emergency expenses; $D E M_{i}$ is a vector of demographic attributes and includes $A G E, E D U C, G E N D E R, R A C E, E T H N I C I T Y, R U R A L ; I N C_{i}$ includes INCOME and HOMEOWNERSHIP; EMP $i$ includes EMPLOYMENT, an indicator of whether consumer $i$ is employed, unemployed, retired, or not in the labor force; $E M P_{i}$ also includes SECTOR, which indicates whether consumer $i$ (if employed) is working for the government, working for the private sector, or is self-employed.

For $Y_{i}=\left\{E_{i}, P_{i}\right\}$ the dependent variables are censored. For $Y_{i}=\left\{E_{i}\right\}$, the total amount saved for emergencies, the dependent variable is censored from below (anything less than $\$ 0$ is considered $\$ 0$ ), while for $Y_{i}=\left\{P_{i}\right\}$, the amount out of $\$ 2,000$ that a consumer can cover in one month, the dependent variable is censored from above and from below (if the amount is greater than $\$ 2,000$, it will be considered $\$ 2,000$, thus unobserved). Many consumers are clustered at the limits (at $\$ 0$ or $\$ 2,000$ ) due to this censoring. As a result, OLS provides inconsistent estimates; censored regression models, such as tobit, should be applied instead. Therefore, we use a tobit model of the amount consumers can cover in one month to estimate regressions on demographics and income and calculate the mean marginal effect on the expected value of the censored (observed) outcome.

When $Y_{i}=\left\{E 0_{i}, P 0_{i}\right\}$, we estimate the regressions using a probit model. The regression results are reported in Table 7. All of the regression results, for both probit and tobit models, are reported as marginal effects. For tobit models, we report marginal effects on the expected value of the censored outcome. 


\section{a. Amount of emergency savings}

In column (1), we report the marginal effects based on estimated coefficients from a tobit regression of the amount of emergency savings. Income, education, and gender have a strong and significant effect on the amount of emergency savings, even after we control for all other demographic and employment variables. Relative to consumers with an annual household income greater than $\$ 100,000$, those in the lowest income group have saved $\$ 11,200$ less for emergencies, on average, and those in the second-lowest income group ( $\$ 25,000$ to $\$ 49,999)$ have saved $\$ 10,500$ less. Relative to consumers with a graduate degree, those with any other level of education have saved significantly less, even when we control for income. Men have saved $\$ 2,800$ more than women, on average, after we control for income and education. Retired consumers seem to be the most financially prepared; on average, a retiree has $\$ 8,700$ more in savings than an employed individual does, when we control for age and income. Working for the government does not significantly affect the amount a person saves or any of the other measures of financial readiness. Consumers living in rural areas have saved \$1,500 less than those living in urban areas, possibly because they have a closer social network they could rely on, but the coefficient is not statistically significant.

\section{b. Saved $\$ 0$ for emergencies}

In column (2), we report the marginal effects based on estimated coefficients from a probit regression of having saved $\$ 0$ for emergencies. People with no emergency savings are likely to be the most financially vulnerable. Most of the demographic variables are significant in the regression. Lower-income, least-educated, unemployed, and black consumers are most likely to have \$0 saved for emergency expenses. Conversely, the most highly educated, highest-income, home-owning, employed, and older consumers are least likely to have $\$ 0$ emergency savings. When we control for age, people with less than a high school degree are 30 percent more likely to have zero savings than are those with a graduate degree, and people in the lowest-income cohort are 33 percent more likely to have saved nothing, compared with those whose income is greater than $\$ 100,000$. The oldest consumers are least likely to have saved $\$ 0$. Unemployed consumers are 8 percent more likely than employed consumers to have no savings. 


\section{c. Amount out of $\$ 2,000$ for emergency expense}

In column (3), we report the marginal effects based on estimated coefficients from a tobit regression of the amount out of $\$ 2,000$ a consumer could cover within a month. All of the demographic, financial, and employment variables significantly affect the amount a consumer could cover. The amounts that lower-income, less-educated, unemployed, and black consumers could come up with if faced with an emergency expense are significantly lower, compared with their counterparts' capabilities. In particular, people earning less than $\$ 25,000$ a year could cover $\$ 896$ less than those earning more than $\$ 100,000$ a year. The lowest-educated consumers could cover $\$ 318$ less than those with a graduate degree. Men could cover $\$ 134$ more than women, on average, and homeowners could cover $\$ 206$ more than renters. Race is also significantly correlated with the amount, even after we control for income and education; black consumers could cover $\$ 191$ less than white consumers, on average. Consumers 65 and older could cover more than any other age cohort, although the payment capabilities of people in the pre-retirement age cohort of 55 to 64 are not significantly different from those of retirees. Even after we control for age, retired consumers could cover $\$ 103$ more than employed individuals, while those who are unemployed could cover $\$ 122$ less. Rural-area dwellers could cover significantly less than their urban counterparts, again possibly because they could rely on a close network for financial support.

\section{d. Could cover $\$ 0$ out of $\$ 2,000$ expense in a month}

In column (4), we report the marginal effects based on estimated coefficients from a probit regression of whether a person could cover $\$ 0$ toward an emergency expense. Despite a relatively high R-squared, few coefficients are statistically significant. This suggests that factors beyond observable demographic and financial attributes, possibly personality traits, lead to a consumer's complete lack of readiness for unexpected expenses. Lowest-income consumers are 14 percent more likely to have $\$ 0$ than are those with an income greater than $\$ 100,000$. Black and disabled consumers are also significantly more likely to come up with $\$ 0$, while homeowners are less likely. 
All of the results discussed here suggest that there is substantial heterogeneity in the degree to which consumers are prepared to face financial emergencies. The lowest-income and least-educated consumers are the least prepared. Individuals who do not own a home are also significantly less likely to be able to cover emergency expenses, and they do not have the ability to obtain home equity loans if needed. Black consumers are more likely to have nothing saved, everything else being equal. For these consumers, even a temporary financial shock, such as a layoff or a short-term government shutdown, could have severe financial consequences. For example, Mian and Sufi (2010) show that household leverage is a strong predictor of a subsequent decline in consumption.

\section{Emergency savings and credit card use}

Our data come from a payments survey that provides detailed records of consumers' payment behavior, in addition to the information about emergency savings. The payment behavior includes payment instrument holdings and instrument use for individual transactions. We employ these data to explore the relationship between emergency savings and payments behavior to test whether people with little or no emergency savings rely more heavily on credit cards, compared with other consumers. If a consumer revolves his credit card debt instead of paying it off at the end of each month, his payment habits could be very costly, and without an adequate financial cushion, he might be forced to borrow even more when faced with an emergency expense. Given the high cost of credit card debt, consumers lacking financial security are likely to weaken their financial situation (Stango and Zinman 2016).

\section{a. Credit cards as a payment instrument}

We measure payment use as the share of the number of transactions conducted with a given payment instrument (Appendix Table 1). Because the emergency amount consumers could cover increases monotonically with income, payment method use by emergency amount resembles payment method use by income (Table 8). In particular, cash use diminishes with the amount consumers could obtain within a month: Those who said they could come up with $\$ 0$ to cover an emergency expenditure use cash for 47 percent of their transactions by volume and 41.5 percent 
by value. In contrast, consumers who could cover the full $\$ 2,000$ use cash for only 28.6 percent of their transactions by volume and 18.1 percent by value.

The relationship between credit card use and emergency coverage is reversed: Consumers who could come up with $\$ 0$ use credit cards for only 1.9 percent of their transactions by volume and 2.4 percent by value, while those who could cover the full amount use credit cards for 25.6 percent of their transactions by volume and 25.9 percent by value, on average. Debit card use does not exhibit a clear pattern based on the amount consumers could secure to cover an unexpected expense. The high use of cash among those who could cover $\$ 0$ holds regardless of whether they have a credit card, because even consumers in this group who do have a credit card are unlikely to use it for purchases.

\section{b. Credit cards as a source of credit}

Even though credit cards are used less frequently as a means of payment among consumers who could not cover an emergency expense, there is evidence that these consumers rely on credit cards as a source of credit. Table 9 shows that the percentage of revolvers is highest among cardholders who could not obtain at least $\$ 500$ for an emergency (79 percent of all cardholders revolve), and it is lowest for cardholders who could cover the full amount (46 percent). Revolvers who could not cover at least $\$ 500$ also carry a higher-than-average balance on their credit cards $(\$ 5,605)$, although their mean balance is not the highest among the cohorts.

The percentage of consumers who rely on credit cards for emergency expenses is approximately the same for all income cohorts; for each of the cohorts with income greater than $\$ 50,000$ a year, approximately 18 percent of consumers and 20 percent of credit card adopters rely on credit cards (Table 10). However, higher-income consumers are less likely to revolve on credit cards: About three quarters of consumers with an annual household income of less than $\$ 25,000$ who rely on credit cards to cover emergencies revolve on their credit cards, compared with just over 40 percent of households with more than $\$ 200,000$ in annual income. For consumers who revolve on credit cards, the cost of using credit cards is much higher than the cost faced by consumers who pay their balances in full. This is because revolvers do not have a grace period (the period between the end of a billing cycle and the payment due date, about four 
weeks). As a result, they accrue daily interest on their existing balance as well as on any new purchases. In contrast, convenience users, who pay their balance in full, do not pay interest and are likely receiving rewards on their transactions, such as cash back or frequent flier miles.

Because the reliance on credit cards for emergencies is inversely correlated with income and positively correlated with credit card revolving, credit card use is likely to increase existing disparities in wealth. While higher-wealth consumers are likely to benefit from using credit cards by getting cash back and float during a grace period and other perks, lower-wealth consumers are more likely to add to their existing debt by accruing high fees and interest costs. Grodzicki and Koulayev (2019) show that 80 percent of outstanding credit card balances are debt revolved for at least a month, and the majority are revolved for many months or even years. Thus the cost of relying on credit cards for emergencies is likely very high for consumers who are already carrying credit card debt.

\section{c. Regressions controlling for demographics and income}

We test whether the relationship between emergency savings and credit card use still exists after we control for income and demographic attributes. Following Stavins and Schuh (2010, 2013), we estimate a two-stage Heckman model of payment method adoption and use, where the use of a payment instrument by a consumer is conditional on the adoption of that payment instrument.

In stage 1, the adoption of payment method $j$ by consumer $i$ is modeled as:

$$
\operatorname{Pr}\left(A_{i j}=1\right)=A\left(X_{i}, \overline{R C H A R}_{i j}\right)+\varepsilon_{i j}^{A},
$$

where

$$
A_{i j} \equiv \begin{cases}1 & \text { if consumer } i \text { has adopted payment instrument } j \\ 0 & \text { otherwise. }\end{cases}
$$

$X_{i}$ is a vector of control variables for consumer $i$ (demographic variables such as age, gender, race, education, and financial variables including income and employment), $\overline{R C H A R}_{i j}$ is a vector 
of average characteristics of payment $j$ relative to the characteristics of all other payment instruments (see the Appendix for a description of how the relative characteristics are created), and $\varepsilon_{i j}^{A}$ is the error term.

Conditional on adoption, we model the use of payment instrument $j$ by consumer $i$ as follows:

$$
U_{i j}=U\left(\operatorname{EMERGESAV}_{i}, X_{i}, \overline{\operatorname{RCHAR}}_{i j}, M R_{i}^{-1}\right)+\varepsilon_{i j}^{U},
$$

where $U_{i j} \equiv\left(n_{i j} / N_{i}\right)$ is the share of the number of payments consumer $i$ made using payment $j$ over the total number of payments made by consumer $i$ in a month, and $N_{i} \equiv \sum_{j} n_{i j}$ is the total number of payments made by consumer $i$ using all payment instruments $j ; E M E R G S A V_{i}$ is a measure of emergency savings by consumer $i$ (total amount saved or readiness to cover a $\$ 2,000$ emergency expense); $M R_{i}^{-1}$ is the inverse Mills ratio from the first-stage Heckman probit model to control for simultaneity of the payment adoption and use decisions; and $\varepsilon_{i j}^{U}$ is the error term.

The relevant coefficients from the regressions of cash, credit card, and debit card use are shown in Table $11 .{ }^{13}$ Even after we control for income, employment, age, and all other demographic attributes, the more consumers save for emergencies, the more they use their credit cards and the less they use their debit cards (there is no significant effect on cash use). Consumers who could cover the full $\$ 2,000$ emergency expense have a 6.8 percent higher share of credit card transactions, while their share of debit card transactions is 7.9 percent lower and their share of cash transactions is 3.1 percent lower, compared with consumers who could not cover the expense within a month.

Even after we control for income, education, and age, the results indicate that consumers who are less prepared to handle financial emergencies are also less likely to use credit cards for transactions. That is reassuring, because, as noted above, relying on credit cards might be very expensive for consumers who have no financial cushion. Note that the use results are based on the

\footnotetext{
${ }^{13}$ Full regression results are available from the author.
} 
Heckman regression and therefore are conditional on adoption of credit cards. Thus, consumers who may have been rejected for credit cards are not included in the use regression. In addition, each payment method use is measured as a share of all transactions, so differences among consumers in the overall number of transactions do not affect those results.

\section{d. Reliance on cash}

Credit cards allow consumers to borrow money and therefore enable them to increase their debt. In contrast, cash must be obtained prior to a transaction, and using or holding cash might help consumers avoid going into debt. We examine consumers' reliance on cash as a source of liquidity.

Cash constitutes an important source of emergency funds for lower-income consumers. Consumers in the lowest income cohort use cash for 43 percent of their transactions (Appendix Table 1). Overall, 19 percent of consumers would use cash to cover some or all of a $\$ 2,000$ unexpected expense (Table 12), but that fraction declines with income: While 30 percent of consumers with an income of less than $\$ 25,000$ would rely on cash, only 3.4 percent of those with an income greater than $\$ 200,000$ would do so (Appendix Table 2). The average amount that would be drawn from cash is $\$ 124$, but the lowest-income consumers would draw $\$ 150$ from cash, compared with only $\$ 30$ by the highest-income consumers. Among consumers who would rely on cash to cover some or all of an unexpected $\$ 2,000$ expense, the average amount is $\$ 651$, or 62 percent of the total amount they could cover (Table 12 and Table 2).

Cash use is concentrated among lower-income people; consumers who could not cover any amount of an emergency expense use cash for almost half of their transactions, whereas those who could cover the full $\$ 2,000$ use cash for just over a quarter of their transactions.

\section{Income shocks and credit card borrowing}

Even temporary changes in income, such as those caused by a government shutdown, can affect consumption, at least in the short run. Gelman et al. (2018) show that following the 2013 government shutdown, consumer spending dropped sharply. Although consumption rebounded after back pay was issued, the way affected workers smoothed their consumption during the shutdown was costly for some, because it involved delaying debt payments. The longer-term 
effect on households' financial well-being varied. The authors of the study note, "Especially among households with chronically low liquid assets or high debt, using payment deferral to smooth consumption could lead to financial distress in the face of shocks such as job loss or poor health that persistently reduce income."

Baker and Yannelis (2017) examine the effect of the 2013 shutdown and find that consumption is highly sensitive to even a temporary income shock. More generally, Baker (2018) finds that elasticity of consumption with respect to income is significantly higher among households with higher levels of debt. The higher sensitivity stems from liquidity and credit constraints. Liquidity-constrained households thus are more likely to change their consumption patterns than are households that are not liquidity constrained. Therefore, households that have little or nothing saved for emergencies and households that would have to borrow to cover an emergency expense are more likely to reduce their consumption, compared with households that have sufficient emergency savings.

Using panel data, we examine whether households that experience a substantial drop in income increase their credit card borrowing. We track consumers who were in the panel in both 2016 and 2017 and analyze changes in their household income between the two years. We then examine how the year-to-year changes in income relate to changes in credit card use in general, with a focus on any changes in borrowing on credit cards.

The annual household income is reported as a set of 18 cohorts, or "buckets," starting with less than $\$ 5,000$ a year and ending with greater than $\$ 500,000$ a year. Figure 3 plots the distribution of the number of consumers within each household income cohort in 2017, and Figure 4 shows the distribution of the changes in income between 2016 and 2017. Almost half of the panelists remained in the same income cohort in the two consecutive years: 1,236 out of 2,681 panelists. The majority of those whose income changed between the two years moved only one cohort up or down; nearly 800 of the remaining 1,445 moved by one cohort. 
We test whether changes in income influence changes in credit card borrowing. ${ }^{14} \mathrm{We}$ estimate the probability of revolving on credit cards on a set of demographic and financial variables using a probit model:

$\operatorname{Pr}($ revolver $)=f($ DEMOGRAPHIC, INCOME,inc_dec $)$

$\operatorname{Pr}($ revolver $)=f($ DEMOGRAPHIC,INCOME, inc_inc $)$,

where revolver $=1$ if a consumer carried unpaid balance at some point during the past 12 months ( 0 otherwise), inc_dec $=1$ if a consumer's income decreased to a lower cohort ( 0 otherwise), and inc_inc $=1$ if a consumer's income increased to a higher cohort ( 0 otherwise). Neither inc_inc nor inc_dec is statistically significant in the regression. We do not find any evidence that people whose income drops substantially are more likely to carry debt on their credit cards. ${ }^{15}$

Next we test whether changes in income have a significant effect on the amount left unpaid on credit cards:

unpaid $=f($ DEMOGRAPHIC, INCOME, inc_dec $)$

unpaid $=f($ DEMOGRAPHIC, INCOME,inc_inc $)$,

where unpaid is the amount unpaid in the past month, conditional on revolving. As above, neither inc_inc nor inc_dec is statistically significant in the regression. We do not find any evidence that people whose income changes in one given year increase or decrease their credit card borrowing the following year.

To test whether the magnitude of income change affects credit card borrowing, we create a discrete variable equal to the difference in the number of cohorts between 2016 and 2017 (intensive margin, rather than the extensive margin above). If a consumer's income did not change, the variable equals 0 . The variable ranges from -12 to 14, as shown in Figure 4. We include the variable in the $\operatorname{Pr}($ revolver $)$ and in the unpaid regressions instead of the income

\footnotetext{
${ }^{14} \mathrm{We}$ can identify changes in income only if they are large enough to cause a shift across cohorts. We cannot identify changes within cohorts.

${ }^{15}$ All of the regression results described in this section are available from the author.
} 
increase/decrease indicator. The variable is not statistically significant. Thus the magnitude of income change seems to have little or no relationship with either the probability of being a revolver or the amount of the unpaid balance.

For robustness, we repeat the analysis for panelists who are in the sample in three consecutive years: 2015, 2016, and 2017. We test whether respondents whose income decreased between 2015 and 2016 were more likely to revolve on their credit cards the following year, and whether the amount they borrowed increased. We do not find evidence that consumers who experienced a drop in income between 2015 and 2016 were more likely to start revolving their credit card debt, either in 2016 or the following year, 2017. After controlling for demographics and income, we find no evidence suggesting that a negative income shock is correlated with the probability of being a revolver or with the unpaid balance.

\section{Conclusions}

Many consumers are not prepared to face unexpected expenses. Consequences of such a lack of financial cushion can be severe. Gelman, et al. (2018) find that households with low liquid assets or high debt could suffer financial distress if they experience an income shock. Because consumers who have little or no emergency savings are more likely to revolve on credit cards, they are likely to weaken their financial situation due to the additional, high cost of such borrowing. Financial literacy might be especially useful for consumers who lack emergency savings, possibly helping them avoid costly consequences of income shocks or unexpected but unavoidable expenses. Specifically, warning revolvers how much each credit card transaction will cost them in terms of additional interest and fees might encourage them to shift to alternative payment methods in the short run and to increase their emergency savings in the longer run. 


\section{References}

Babiarz, Patryk, and Cliff Robb. 2014. "Financial Literacy and Emergency Saving." Journal of Family and Economic Issues 35(1): 40-50.

Baker, Scott R. 2018. "Debt and the Response to Household Income Shocks: Validation and Application of Linked Financial Account Data.” Journal of Political Economy 126(4): 1504-1557.

Baker, Scott R., and Constantine Yannelis. 2017. "Income Changes and Consumption: Evidence from the 2013 Federal Government Shutdown.” Review of Economic Dynamics 23 (January): 99-124. https://doi.org/10.1016/j.red.2016.09.005

Bhutta, Neil, and Lisa Dettling. 2018. "Money in the Bank? Assessing Families' Liquid Savings Using the Survey of Consumer Finances." Board of Governors of the Federal Reserve System FEDS Notes. https://www.federalreserve.gov/econres/notes/fedsnotes/assessing-families-liquid-savings-using-the-survey-of-consumer-finances$\underline{20181119 . h t m}$

Board of Governors of the Federal Reserve System. 2019. Report on the Economic Well-Being of U.S. Households in 2018. https://www.federalreserve.gov/publications/files/2018-reporteconomic-well-being-us-households-201905.pdf.

Gabler, Neal. 2016. "The Secret Shame of Middle-Class Americans." The Atlantic. Accessed at: https://www.theatlantic.com/magazine/archive/2016/05/my-secret-shame/476415/

Gelman, Michael, Shachar Kariv, Matthew D. Shapiro, Dan Silverman, and Steven Tadelis. 2018. "How Individuals Respond to a Liquidity Shock: Evidence from the 2013 Government Shutdown.” Journal of Public Economics. https://doi.org/10.1016/j.jpubeco.2018.06.007 (revised in January 2019).

Greene, Claire, and Joanna Stavins. 2018. "The 2017 Diary of Consumer Payment Choice." Federal Reserve Bank of Atlanta Research Data Reports No. 18-05. https://www.frbatlanta.org/banking-and-payments/consumer-payments/research-datareports/2018/the-2017-diary-of-consumer-payment-choice.aspx

Grodzicki, Daniel, and Sergei Koulayev. 2019. "Sustained Credit Card Borrowing."

Kennickell, Arthur, and Annamaria Lusardi. 2004. "Disentangling the Importance of the Precautionary Saving Mode.” NBER Working Paper No. 10888

Lusardi, Annamaria, Daniel Schneider, and Peter Tufano. 2011. "Financially Fragile Households: Evidence and Implications." Brookings Papers on Economic Activity (Spring): 83-134. https://www.brookings.edu/wpcontent/uploads/2011/03/2011a_bpea_lusardi.pdf 
Mian, Atif, and Amir Sufi. 2010. "Household Leverage and the Recession of 2007-09." IMF Economic Review 58(1): 74-117. https://link.springer.com/article/10.1057\%2Fimfer.2010.2

Pence, Karen M. 2011. "Comment on 'The Financially Fragile Households: Evidence and Implications,"” Brookings Papers on Economic Activity (Spring): 141-150.

Schuh, Scott, and Joanna Stavins. 2010. "Why Are (Some) Consumers (Finally) Writing Fewer Checks? The Role of Payment Characteristics." Journal of Banking and Finance 34(8): $1745-1758$.

Schuh, Scott, and Joanna Stavins. 2013. "How Consumers Pay: Adoption and Use of Payments." Accounting and Finance Research 2(2): 1-21. https://doi.org/10.5430/afr.v2n2p1

Stango, Victor and Jonathan Zinman. 2016. "Borrowing High versus Borrowing Higher: Price Dispersion and Shopping Behavior in the U.S. Credit Card Market." The Review of Financial Studies 29(4): 979-1006. https://doi.org/10.1093/rfs/hhv072. 
Table 1: Amount saved for emergency expenses, by source of funds

\begin{tabular}{lccccc}
\hline & Cash & Check & Savings & Prepaid & Total \\
\hline $\begin{array}{l}\text { Mean amount from each source: } \\
\quad \text { full sample }\end{array}$ & $\$ 338$ & $\$ 2,738$ & $\$ 8,685$ & $\$ 66$ & $\$ 11,724$ \\
$\quad$ those with nonzero amount only & $\$ 893$ & $\$ 5,746$ & $\$ 16,178$ & $\$ 673$ & $\$ 15,618$ \\
$\quad \%$ of consumers saved $\$ 0$ & $62 \%$ & $52 \%$ & $46 \%$ & $25 \%$ \\
\hline Number of non-missing observations & 2750 & 2751 & 2754 & 2731 & 2775 \\
\hline
\end{tabular}

Source(s): 2017 Diary of Consumer Payment Choice

Note(s): Sampling weights were applied to all statistics with the exception of the number of non-missing observations. 
Table 2: Amount covered in one month if facing $\$ 2,000$ emergency expense, by source of funds

\begin{tabular}{|c|c|c|c|c|c|c|c|c|c|}
\hline & Cash & $\begin{array}{c}\text { Checking } \\
\text { Account }\end{array}$ & Overdraft & Credit & HELOC & $\begin{array}{l}\text { Savings } \\
\text { account }\end{array}$ & $\begin{array}{l}\text { Payday } \\
\text { loan }\end{array}$ & $\begin{array}{l}\text { Family } \\
\qquad \& \\
\text { friend }\end{array}$ & $\begin{array}{c}\text { Pawn } \\
\text { shop }\end{array}$ \\
\hline $\begin{array}{l}\text { Used to cover part (or all) of } \$ 2,000 \\
\text { emergency expense, } \% \text { of } \\
\text { consumers }\end{array}$ & $19.0 \%$ & $38.2 \%$ & $2.1 \%$ & $17.5 \%$ & $1.6 \%$ & $34.3 \%$ & $2.2 \%$ & $12.8 \%$ & $1.2 \%$ \\
\hline $\begin{array}{l}\text { Mean amount from each source } \\
\text { (nonzero only) }\end{array}$ & $\$ 651$ & $\$ 1,079$ & $\$ 624$ & $\$ 1,275$ & $\$ 1,218$ & $\$ 1,435$ & $\$ 416$ & $\$ 862$ & $\$ 318$ \\
\hline $\begin{array}{l}\text { Mean source of fund shares, as a } \\
\text { percentage of amount payable }\end{array}$ & $12.6 \%$ & $30.5 \%$ & $1.2 \%$ & $14.1 \%$ & $1.2 \%$ & $29.5 \%$ & $1.1 \%$ & $10.0 \%$ & $0.4 \%$ \\
\hline $\begin{array}{l}\text { Mean source of fund shares } \\
\text { (nonzero only), as a percentage of } \\
\text { amount payable }\end{array}$ & $61.8 \%$ & $74.6 \%$ & $50.9 \%$ & $74.9 \%$ & $70.3 \%$ & $80.0 \%$ & $49.3 \%$ & $72.8 \%$ & $30.5 \%$ \\
\hline
\end{tabular}

Source(s): 2017 Diary of Consumer Payment Choice

Note(s): Sampling weights were applied to all statistics. 
Table 3: Emergency-savings-related measures, by demographics and income

\begin{tabular}{|c|c|c|c|c|c|c|c|}
\hline & & $\begin{array}{c}\text { Average } \\
\text { emergency } \\
\text { savings (\$) }\end{array}$ & $\begin{array}{c}\text { Did not save } \\
\text { for } \\
\text { emergency } \\
(\%)\end{array}$ & $\begin{array}{c}\text { Average } \\
\text { amount can } \\
\text { cover out of } \\
\$ 2,000(\$)\end{array}$ & $\begin{array}{c}\text { Can Cover } \$ 0 \\
\text { in } 1 \text { month if } \\
\text { facing } \$ 2,000 \\
(\%)\end{array}$ & $\begin{array}{c}\text { Can Cover } \\
\text { full amount } \\
\text { in } 1 \text { month if } \\
\text { facing } \$ 2,000 \\
(\%)\end{array}$ & $\begin{array}{l}\text { Percentage of } \\
\text { all consumers } \\
\qquad(\%)\end{array}$ \\
\hline Overall & & $\$ 11,724$ & 24.9 & $\$ 1,395$ & 6.9 & 58.5 & 100.0 \\
\hline \multirow{7}{*}{ Age } & Under 25 & $\$ 1,223$ & 44.7 & $\$ 1,156$ & 15.8 & 40.1 & 4.9 \\
\hline & $25-34$ & $\$ 5,137$ & 29.3 & $\$ 1,246$ & 8.1 & 48.6 & 24.8 \\
\hline & $35-44$ & $\$ 8,891$ & 24.9 & $\$ 1,412$ & 5.8 & 57.5 & 16.2 \\
\hline & $45-54$ & $\$ 12,680$ & 20.2 & $\$ 1,492$ & 7.6 & 65.2 & 16.8 \\
\hline & $55-64$ & $\$ 11,578$ & 23.7 & $\$ 1,456$ & 4.7 & 61.8 & 17.2 \\
\hline & Over 64 & $\$ 24,040$ & 19.6 & $\$ 1,490$ & 5.3 & 67.6 & 20.1 \\
\hline & $\begin{array}{r}\text { Significantly } \\
\text { Different? }\end{array}$ & $* * *$ & $* * *$ & $* * *$ & $* * *$ & $* * *$ & -- \\
\hline \multirow{6}{*}{ Education } & Less than high school & $\$ 858$ & 55.6 & $\$ 820$ & 17.8 & 26.3 & 7.0 \\
\hline & High school & $\$ 5,621$ & 31.8 & $\$ 1,211$ & 9.8 & 46.5 & 32.6 \\
\hline & Some college & $\$ 10,976$ & 31.8 & $\$ 1,310$ & 8.4 & 52.4 & 17.4 \\
\hline & College & $\$ 11,847$ & 14.5 & $\$ 1,610$ & 2.3 & 71.5 & 28.7 \\
\hline & Graduate & $\$ 31,615$ & 7.1 & $\$ 1,765$ & 2.2 & 82.9 & 14.3 \\
\hline & $\begin{array}{r}\text { Significantly } \\
\text { Different? } \\
\end{array}$ & $* * *$ & $* * *$ & $* * *$ & $* * *$ & $* * *$ & -- \\
\hline \multirow[t]{3}{*}{ Gender } & Male & $\$ 11,450$ & 23.9 & $\$ 1,480$ & 5.5 & 63.4 & 47.8 \\
\hline & Female & $\$ 11,975$ & 25.9 & $\$ 1,317$ & 8.1 & 54.1 & 52.2 \\
\hline & $\begin{array}{r}\text { Significantly } \\
\text { Different? }\end{array}$ & & 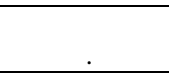 & $* * *$ & $* * *$ & $* * *$ & -- \\
\hline \multirow{6}{*}{ Income } & Less than 25,000 & $\$ 4,206$ & 48.5 & $\$ 703$ & 22.9 & 20.8 & 17.5 \\
\hline & $25,000-49,999$ & $\$ 5,595$ & 35.4 & $\$ 1,225$ & 9.2 & 45.5 & 23.3 \\
\hline & $50,000-74,999$ & $\$ 8,940$ & 20.6 & $\$ 1,437$ & 1.5 & 59.3 & 19.9 \\
\hline & $75,000-99,999$ & $\$ 13,465$ & 17.0 & $\$ 1,644$ & 1.9 & 71.9 & 12.7 \\
\hline & More than 100,000 & $\$ 23,388$ & 7.4 & $\$ 1,844$ & 0.8 & 87.6 & 26.3 \\
\hline & $\begin{array}{r}\text { Significantly } \\
\text { Different? }\end{array}$ & $* * *$ & $* * *$ & $* * *$ & $* * *$ & $* * *$ & -- \\
\hline \multirow[t]{3}{*}{ Ethnicity } & Latino & $\$ 3,997$ & 27.7 & $\$ 1,261$ & 6.5 & 46.1 & 11.9 \\
\hline & Non-Latino & $\$ 12,755$ & 24.6 & $\$ 1,414$ & 6.9 & 60.2 & 88.1 \\
\hline & $\begin{array}{r}\text { Significantly } \\
\text { Different? }\end{array}$ & $* * *$ & . & $* * *$ & . & $* * *$ & -- \\
\hline \multirow{5}{*}{ Race } & White & $\$ 13,564$ & 22.4 & $\$ 1,470$ & 4.8 & 63.0 & 80.5 \\
\hline & Black & $\$ 2,173$ & 39.9 & $\$ 990$ & 17.8 & 33.9 & 14.6 \\
\hline & Asian & $\$ 10,723$ & 18.6 & $\$ 1,590$ & 2.8 & 67.9 & 5.1 \\
\hline & Other & $\$ 1,308$ & 38.7 & $\$ 699$ & 23.7 & 26.0 & 1.3 \\
\hline & $\begin{array}{r}\text { Significantly } \\
\text { Different? }\end{array}$ & $* * *$ & $* * *$ & $* * *$ & $* * *$ & $* * *$ & -- \\
\hline \multirow{3}{*}{$\begin{array}{l}\text { Home } \\
\text { Ownership }\end{array}$} & Home owner & $\$ 16,314$ & 17.4 & $\$ 1,588$ & 3.3 & 70.2 & 65.4 \\
\hline & Non-home owner & $\$ 3,049$ & 39.2 & $\$ 1,032$ & 13.6 & 36.6 & 34.6 \\
\hline & $\begin{array}{r}\text { Significantly } \\
\text { Different? }\end{array}$ & $* * *$ & $* * *$ & $* * *$ & $* * *$ & $* * *$ & -- \\
\hline \multirow{5}{*}{$\begin{array}{l}\text { Working } \\
\text { Status }\end{array}$} & Employed & $\$ 8,965$ & 21.8 & $\$ 1,479$ & 4.4 & 61.8 & 64.0 \\
\hline & Unemployed & $\$ 3,538$ & 54.0 & $\$ 770$ & 21.4 & 25.9 & 6.5 \\
\hline & Disabled or other & $\$ 5,038$ & 36.8 & $\$ 1,004$ & 15.4 & 36.6 & 11.2 \\
\hline & Retired & $\$ 28,161$ & 18.4 & $\$ 1,556$ & 5.3 & 71.5 & 18.2 \\
\hline & $\begin{array}{r}\text { Significantly } \\
\text { Different? }\end{array}$ & $* * *$ & $* * *$ & $* * *$ & $* * *$ & $* * *$ & -- \\
\hline \multirow{4}{*}{ Residence } & Rural & $\$ 10,030$ & 24.3 & $\$ 1,390$ & 6.1 & 60.3 & 14.7 \\
\hline & Mixed clusters & $\$ 10,725$ & 26.3 & $\$ 1,404$ & 6.9 & 59.4 & 55.5 \\
\hline & Urban & $\$ 11,305$ & 23.4 & $\$ 1,380$ & 6.8 & 57.6 & 29.8 \\
\hline & $\begin{array}{r}\text { Significantly } \\
\text { Different? }\end{array}$ & & 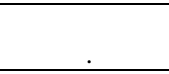 & 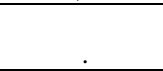 & & . & -- \\
\hline
\end{tabular}

Source(s): 2017 Diary of Consumer Payment Choice

Note(s): Sampling weights were applied to all statistics. 
Table 4: Stated ability to pay (out of $\$ 2,000)$ vs. actual balance, non-debt sources only (cash and checking account)

\begin{tabular}{|c|c|}
\hline & Percent \\
\hline $\begin{array}{l}\text { Can cover stated checking account balance and cash amount } \\
\text { (no funds drawn from savings) } \\
\text { \% of all consumers }\end{array}$ & $29.9 \%$ \\
\hline $\begin{array}{l}\text { Cannot cover either stated checking account balance or cash amount } \\
\text { (no funds drawn from saving) } \\
\text { \% of all consumers }\end{array}$ & $35.9 \%$ \\
\hline \multicolumn{1}{|l|}{$\begin{array}{l}\text { Insufficient cash amount, but can cover checking account balance } \\
\text { \% of consumers who cannot cover either }\end{array}$} & $22.7 \%$ \\
\hline $\begin{array}{l}\text { Insufficient checking account balance, but can cover cash amount } \\
\text { \% of consumers who cannot cover either }\end{array}$ & $71.4 \%$ \\
\hline $\begin{array}{l}\text { Insufficient cash and checking account balance } \\
\text { \% of consumers who cannot cover either }\end{array}$ & $5.8 \%$ \\
\hline $\begin{array}{l}\text { Cannot be confirmed } \\
\text { (positive amount drawn from savings account or missing) }\end{array}$ & \\
\hline \begin{tabular}{l} 
all consumers \\
\hline
\end{tabular} & $34.2 \%$ \\
\hline
\end{tabular}

Note(s): Due to limitations of our questionnaire, we can compare only two sources with their balances: cash and checking account. We assume respondents have the ability to acquire the debt portion of the emergency expense (the sum of funds comes from overdraft, credit card, HELOC, family or friend, pawn shop and payday loan). The non-debt portion of the stated emergency fund comes from three possible sources: cash, checking account, and savings account. Unfortunately we did not ask the respondents their savings account balance, so we can't confirm anything about a respondent who indicates a positive amount of emergency funds saved in a savings account. Sampling weights were applied to all statistics. 
Table 5: Emergency-savings-related measures, by job sector

\begin{tabular}{|c|c|c|c|c|c|c|}
\hline Job Sector & $\begin{array}{c}\text { Average } \\
\text { emergency } \\
\text { savings (\$) }\end{array}$ & $\begin{array}{c}\text { Did not save } \\
\text { for emergency } \\
(\%)\end{array}$ & $\begin{array}{c}\text { Average } \\
\text { amount can } \\
\text { cover out of } \\
\$ 2,000(\$)\end{array}$ & $\begin{array}{c}\text { Can Cover } \$ 0 \\
\text { in } 1 \text { month if } \\
\text { facing } \$ 2,000 \\
(\%)\end{array}$ & $\begin{array}{c}\text { Can Cover full } \\
\text { amount in } 1 \\
\text { month if facing } \\
\$ 2,000(\%)\end{array}$ & $\begin{array}{c}\text { Percentage of } \\
\text { employed } \\
\text { consumers }(\%)\end{array}$ \\
\hline Government & $\$ 8,601$ & 16.4 & $\$ 1,605$ & 1.9 & 69.9 & 18.1 \\
\hline Private for-profit & $\$ 8,485$ & 24.6 & $\$ 1,438$ & 5.5 & 58.2 & 59.1 \\
\hline Non-profit & $\$ 9,193$ & 18.2 & $\$ 1,462$ & 3.7 & 64.0 & 15.1 \\
\hline Self-employed & $\$ 11,862$ & 16.0 & $\$ 1,554$ & 1.2 & 68.7 & 7.7 \\
\hline Significantly Different? & & $* * *$ & $* * *$ & $* *$ & $* * *$ & -- \\
\hline
\end{tabular}

Source(s): 2017 Diary of Consumer Payment Choice

Note(s): Sampling weights were applied to all statistics. 
Table 6: Emergency-savings-to-income ratio by demographics and income

\begin{tabular}{|c|c|c|c|c|}
\hline & & $\begin{array}{c}\text { Emergency Savings / } \\
\text { Annual Income } \\
\text { (midpoint) }\end{array}$ & $\begin{array}{c}\text { Weighted Number of } \\
\text { Consumers }\end{array}$ & $\begin{array}{c}\text { Percentage of All } \\
\text { Consumers }(\%)\end{array}$ \\
\hline Overall & & 0.19 & 2774 & 100.0 \\
\hline \multirow{7}{*}{ Age } & Under 25 & 0.03 & 137 & 4.9 \\
\hline & $25-34$ & 0.08 & 688 & 24.8 \\
\hline & $35-44$ & 0.08 & 448 & 16.2 \\
\hline & $45-54$ & 0.12 & 466 & 16.8 \\
\hline & $55-64$ & 0.15 & 476 & 17.2 \\
\hline & Over 64 & 0.54 & 558 & 20.1 \\
\hline & Significantly Different? & $* * *$ & & \\
\hline \multirow{6}{*}{ Education } & Less than high school & 0.02 & 194 & 7.0 \\
\hline & High school & 0.12 & 905 & 32.6 \\
\hline & Some college & 0.40 & 482 & 17.4 \\
\hline & College & 0.13 & 796 & 28.7 \\
\hline & Graduate & 0.27 & 397 & 14.3 \\
\hline & Significantly Different? & $* * *$ & & \\
\hline \multirow{3}{*}{ Gender } & Male & 0.14 & 1327 & 47.8 \\
\hline & Female & 0.23 & 1447 & 52.2 \\
\hline & Significantly Different? & $*$ & & \\
\hline \multirow{6}{*}{ Income } & Less than 25,000 & 0.37 & 335 & 15.9 \\
\hline & $25,000-49,999$ & 0.16 & 413 & 19.6 \\
\hline & $50,000-74,999$ & 0.14 & 406 & 19.3 \\
\hline & $75,000-99,999$ & 0.15 & 307 & 14.6 \\
\hline & More than 100,000 & 0.14 & 645 & 30.6 \\
\hline & Significantly Different? & $* *$ & & \\
\hline \multirow{3}{*}{ Ethnicity } & Latino & 0.05 & 329 & 11.9 \\
\hline & Non-Latino & 0.21 & 2445 & 88.1 \\
\hline & Significantly Different? & $*$ & & \\
\hline \multirow{5}{*}{ Race } & White & 0.22 & 2232 & 80.5 \\
\hline & Black & 0.04 & 406 & 14.6 \\
\hline & Asian & 0.15 & 142 & 5.1 \\
\hline & Other & 0.02 & 37 & 1.3 \\
\hline & Significantly Different? & & & \\
\hline \multirow{3}{*}{$\begin{array}{c}\text { Home } \\
\text { Ownership }\end{array}$} & Home owner & 0.25 & 1813 & 65.4 \\
\hline & Non-home owner & 0.06 & 961 & 34.6 \\
\hline & Significantly Different? & $* * *$ & & \\
\hline \multirow{5}{*}{$\begin{array}{l}\text { Working } \\
\text { Status }\end{array}$} & Employed & 0.09 & 1774 & 64.0 \\
\hline & Unemployed & 0.08 & 181 & 6.5 \\
\hline & Retired & 0.62 & 504 & 18.2 \\
\hline & Disabled or other & 0.09 & 309 & 11.2 \\
\hline & Significantly Different? & $* * *$ & & \\
\hline \multirow{4}{*}{ Residence } & Rural & 0.14 & 349 & 14.7 \\
\hline & Mixed clusters & 0.14 & 1317 & 55.5 \\
\hline & Urban & 0.30 & 706 & 29.8 \\
\hline & Significantly Different? & $*$ & & \\
\hline \multirow{5}{*}{ Job Sector } & Government & 0.10 & 316 & 11.4 \\
\hline & Private for-profit company & 0.08 & 1031 & 37.2 \\
\hline & Non-profit organizations & 0.11 & 263 & 9.5 \\
\hline & Self-employed & 0.15 & 135 & 4.9 \\
\hline & Significantly Different? & $* *$ & & \\
\hline
\end{tabular}

Source(s): 2017 Diary of Consumer Payment Choice

Note(s): Sampling weights were applied to all statistics. 
Table 7: Regression results, ability to cover emergency expenses

\begin{tabular}{|c|c|c|c|c|c|c|c|c|c|}
\hline & \multicolumn{2}{|c|}{$\begin{array}{c}\text { Amount of } \\
\text { emergency savings } \\
\text { (1) }\end{array}$} & \multicolumn{2}{|c|}{$\begin{array}{c}\text { Saved \$0 for } \\
\text { emergency use } \\
(2)\end{array}$} & \multicolumn{2}{|c|}{$\begin{array}{l}\text { Amount out of } \\
\$ 2,000 \text { can come } \\
\text { up in a month } \\
(3)\end{array}$} & \multicolumn{2}{|c|}{$\begin{array}{l}\text { Can cover \$0 } \\
\text { emergency } \\
\text { expense in a } \\
\text { month } \\
(4) \\
\end{array}$} \\
\hline & & Tobit & & Probit & & Tobit & & Probit & \\
\hline \multirow{6}{*}{ Age } & Under 25 & -423.96 & & 0.08 & & -112.98 & & 0.03 & \\
\hline & $25-34$ & -2168.26 & & 0.11 & $* *$ & -231.98 & $* * *$ & 0.04 & \\
\hline & $35-44$ & -1770.90 & & 0.16 & $* * *$ & -180.70 & $* * *$ & 0.03 & \\
\hline & $45-54$ & 1681.51 & & 0.11 & $* *$ & -194.36 & $* * *$ & 0.04 & $*$ \\
\hline & $55-64$ & -87.64 & & 0.08 & $* *$ & -81.60 & & 0.01 & \\
\hline & Over 64 & -- & -- & -- & -- & -- & -- & -- & -- \\
\hline \multirow{5}{*}{ Education } & $\begin{array}{r}\text { Less than high } \\
\text { school }\end{array}$ & -8085.57 & $* * *$ & 0.30 & $* * *$ & -318.48 & $* * *$ & 0.00 & \\
\hline & High school & -7345.54 & $* * *$ & 0.19 & $* * *$ & -312.79 & $* * *$ & 0.02 & \\
\hline & Some college & -4749.20 & $* * *$ & 0.19 & $* * *$ & -214.42 & $* * *$ & 0.00 & \\
\hline & College & -5799.64 & $* * *$ & 0.07 & $* *$ & -58.77 & & -0.01 & \\
\hline & Graduate & -- & -- & -- & -- & -- & -- & -- & -- \\
\hline \multirow{2}{*}{ Gender } & Male & 2811.13 & $* *$ & -0.02 & & 134.46 & $* * *$ & -0.01 & \\
\hline & Female & -- & -- & -- & -- & -- & -- & -- & -- \\
\hline \multirow{5}{*}{ Income } & Less than 25,000 & -11220.70 & $* * *$ & 0.33 & $* * *$ & -896.20 & *** & 0.14 & $* * *$ \\
\hline & $25,000-49,999$ & -10527.11 & $* * *$ & 0.25 & $* * *$ & -575.91 & $* * *$ & 0.07 & $* *$ \\
\hline & $50,000-74,999$ & -6778.27 & $* * *$ & 0.16 & $* * *$ & -390.04 & $* * *$ & 0.03 & \\
\hline & $75,000-99,999$ & -6903.25 & $* * *$ & 0.07 & $*$ & -187.81 & $* * *$ & 0.01 & \\
\hline & $\begin{array}{r}\text { More than } \\
100,000\end{array}$ & 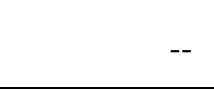 & -- & -- & -- & -- & -- & -- & -- \\
\hline \multirow{2}{*}{ Ethnicity } & Latino & -1788.40 & & -0.01 & & -17.00 & & -0.01 & \\
\hline & Non-Latino & -- & -- & -- & -- & -- & -- & -- & -- \\
\hline \multirow{4}{*}{ Race } & Black & -2587.41 & & 0.07 & $* *$ & -190.95 & $* * *$ & 0.03 & $* *$ \\
\hline & Asian & -812.99 & & 0.02 & & 132.13 & $*$ & -0.01 & \\
\hline & Other & -2737.41 & & -0.02 & & -380.63 & $* *$ & 0.14 & $* *$ \\
\hline & White & -- & -- & -- & -- & -- & -- & -- & -- \\
\hline Home & Home owner & 2017.94 & & -0.12 & $* * *$ & 205.57 & $* * *$ & -0.02 & $* *$ \\
\hline Ownership & Non-home owner & -- & -- & -- & -- & -- & -- & -- & -- \\
\hline \multirow{4}{*}{$\begin{array}{l}\text { Working } \\
\text { Status }\end{array}$} & Unemployed & 4700.64 & $*$ & 0.08 & $*$ & -122.35 & $* *$ & 0.02 & \\
\hline & Retired & 8721.87 & $* * *$ & 0.00 & & 103.30 & $* *$ & 0.02 & \\
\hline & Disabled or other & 2851.00 & & 0.01 & & -123.78 & $* * *$ & 0.04 & $* * *$ \\
\hline & Employed & -- & -- & -- & -- & -- & -- & -- & -- \\
\hline \multirow[t]{2}{*}{ Job Sector } & $\begin{array}{r}\text { Workfor } \\
\text { government }\end{array}$ & -1849.11 & & 0.01 & & 6.60 & & 0.00 & \\
\hline & Other sectors & -- & -- & -- & -- & -- & -- & -- & -- \\
\hline \multirow[t]{2}{*}{ Residence } & $\begin{array}{r}\text { Rural } \\
\text { Mixed clusters }\end{array}$ & $\begin{array}{r}-1497.66 \\
-756.54\end{array}$ & & $\begin{array}{l}0.02 \\
0.02\end{array}$ & & $\begin{array}{l}-67.98 \\
-40.71\end{array}$ & $*$ & $\begin{array}{l}0.00 \\
0.01\end{array}$ & \\
\hline & Urban & -- & -- & -- & -- & -- & -- & -- & -- \\
\hline \multirow{2}{*}{\multicolumn{2}{|c|}{$\begin{array}{l}\text { Pseudo R-squared } \\
\text { Number of Observations }\end{array}$}} & 0.0034 & & 0.1610 & & 0.0582 & & 0.2320 & \\
\hline & & 2395 & & 2395 & & 2400 & & 2400 & \\
\hline
\end{tabular}

Source(s): 2017 Diary of Consumer Payment Choice

Note(s): Regressions in columns (1) and (3) were estimated using tobit models. Regressions in columns (2) and (4) were estimated using probit. All results are reported as marginal effects at means. Reference group marked as "--". 
Table 8: Payment use share by payment instrument, by amount out of $\$ 2,000$ cohort

\begin{tabular}{|c|c|c|c|c|c|c|c|c|c|}
\hline $\begin{array}{c}\text { Can cover this } \\
\text { amount }\end{array}$ & Cash & Check & Credit & Debit & Prepaid & BANP & OBBP & Other & Total \\
\hline \multicolumn{10}{|c|}{ Shares by number of transactions } \\
\hline$\$ 0$ & 47.0 & 5.7 & 1.9 & 29.1 & 4.8 & 2.3 & 2.2 & 7.2 & 100.0 \\
\hline$\$ 0-500$ & 44.2 & 5.9 & 5.8 & 30.5 & 2.4 & 3.6 & 2.9 & 4.6 & 100.0 \\
\hline$\$ 500-1000$ & 40.6 & 5.2 & 7.8 & 32.3 & 1.6 & 4.1 & 3.2 & 5.3 & 100.0 \\
\hline$\$ 1,000-1,500$ & 41.2 & 6.1 & 9.3 & 28.0 & 1.2 & 5.6 & 3.3 & 5.3 & 100.0 \\
\hline$\$ 1,500-2,000$ & 29.8 & 10.7 & 9.5 & 40.1 & 0.4 & 3.5 & 3.3 & 2.7 & 100.0 \\
\hline$\$ 2,000$ & 28.6 & 7.8 & 25.6 & 21.8 & 1.8 & 4.8 & 4.8 & 4.8 & 100.0 \\
\hline Total & 33.4 & 7.1 & 19.0 & 25.0 & 1.9 & 4.5 & 4.1 & 5.0 & 100.0 \\
\hline \multicolumn{10}{|c|}{ Shares by value of transactions } \\
\hline$\$ 0$ & 41.5 & 6.7 & 2.4 & 29.0 & 5.3 & 4.2 & 2.9 & 7.9 & 100.0 \\
\hline$\$ 0-500$ & 38.7 & 7.0 & 6.2 & 31.0 & 1.5 & 5.7 & 4.5 & 5.5 & 100.0 \\
\hline$\$ 500-1,000$ & 34.5 & 7.3 & 8.7 & 31.8 & 1.3 & 5.5 & 4.0 & 6.9 & 100.0 \\
\hline$\$ 1,000-1,500$ & 35.4 & 8.8 & 9.8 & 25.0 & 1.5 & 8.5 & 4.9 & 6.1 & 100.0 \\
\hline$\$ 1,500-2,000$ & 20.3 & 13.9 & 9.8 & 39.2 & 0.6 & 6.3 & 5.1 & 4.8 & 100.0 \\
\hline$\$ 2,000$ & 18.1 & 12.4 & 25.9 & 21.1 & 1.3 & 8.1 & 7.5 & 5.5 & 100.0 \\
\hline Total & 24.5 & 10.7 & 19.4 & 24.3 & 1.5 & 7.4 & 6.4 & 5.8 & 100.0 \\
\hline
\end{tabular}

Source(s): 2017 Diary of Consumer Payment Choice

Note(s): Sampling weights were applied to all statistics. "Other" includes money order, PayPal, account-to-account, mobile, income deduction, and other unspecified payments. 
Table 9: Reliance on credit cards, by amount covered cohort

\begin{tabular}{|c|c|c|c|c|c|c|}
\hline & \multicolumn{2}{|c|}{$\begin{array}{c}\text { Credit Card Use, Share of All } \\
\text { Transactions (\%) }\end{array}$} & \multirow[t]{2}{*}{$\begin{array}{c}\text { Revolvers as a } \\
\% \text { of credit } \\
\text { card adopters }\end{array}$} & \multirow[t]{2}{*}{$\begin{array}{c}\text { Average } \\
\text { Revolver's } \\
\text { Balance (\$) }\end{array}$} & \multirow[t]{2}{*}{$\begin{array}{c}\text { Average } \\
\text { Revolver's } \\
\text { Balance } \\
\text { (nonzero) }\end{array}$} & \multirow[t]{2}{*}{$\begin{array}{c}\% \text { of } \\
\text { Consumers }\end{array}$} \\
\hline & by number & by value & & & & \\
\hline$\$ 0$ & 1.9 & 2.4 & 65.1 & 2454.7 & 2672.5 & 6.9 \\
\hline$\$ 0-500$ & 5.8 & 6.2 & 79.1 & 5031.9 & 5604.9 & 12.2 \\
\hline$\$ 500-1000$ & 7.8 & 8.7 & 72.7 & 3344.0 & 3644.5 & 10.0 \\
\hline$\$ 1000-1500$ & 9.3 & 9.8 & 73.3 & 2944.7 & 3074.3 & 9.4 \\
\hline$\$ 1500-2000$ & 9.5 & 9.8 & 67.8 & 7492.1 & 9237.9 & 3.0 \\
\hline$\$ 2,000$ & 25.6 & 25.9 & 46.2 & 4606.3 & 5635.2 & 58.5 \\
\hline Total & 19.0 & 19.4 & 54.6 & 4322.5 & 5041.2 & 100.0 \\
\hline Number of consumers & \multicolumn{2}{|c|}{$2202^{(a)}$} & \multicolumn{2}{|c|}{$1222^{(b)}$} & $1049^{(\mathrm{c})}$ & \\
\hline
\end{tabular}

Source(s): 2017 Diary of Consumer Payment Choice; 2017 Survey of Consumer Payment Choice

Note(s): (a) Number of credit card adopters. (b) Number of revolvers. (c) Number of revolvers who have nonzero balance.

Sampling weights were applied to all statistics. 
Table 10: Reliance on credit cards, by income cohort

\begin{tabular}{|c|c|c|c|c|}
\hline Income Cohorts & $\begin{array}{c}\text { Consumers who rely on } \\
\text { credit card for } \\
\text { emergency expense, } \\
\% \text { of total consumers } \\
\text { in this cohort }\end{array}$ & $\begin{array}{l}\text { Consumers who rely on } \\
\text { credit card for } \\
\text { emergency expense, } \\
\% \text { of credit card } \\
\text { adopters in this cohort }\end{array}$ & $\begin{array}{c}\text { Revolvers, } \\
\% \text { of consumers who } \\
\text { rely on credit card for } \\
\text { emergency expense }\end{array}$ & $\begin{array}{c}\text { Average amount } \\
\text { (nonzero only) drew } \\
\text { from credit card for } \\
\text { emergency use }\end{array}$ \\
\hline Less than $\$ 25,000$ & 11.1 & 17.1 & 74.3 & 474.3 \\
\hline$\$ 25,000$ - \$49,999 & 20.0 & 28.4 & 69.0 & 1334.8 \\
\hline$\$ 50,000$ - \$74,999 & 18.4 & 20.7 & 80.1 & 1186.3 \\
\hline$\$ 75,000$ - \$99,999 & 18.3 & 20.3 & 78.0 & 1313.2 \\
\hline$\$ 100,000$ - \$124,999 & 18.2 & 19.7 & 62.8 & 1471.4 \\
\hline$\$ 125,000$ - \$199,999 & 18.8 & 20.0 & 47.8 & 1574.5 \\
\hline$\$ 200,000$ and above & 18.3 & 19.5 & 42.5 & 1902.1 \\
\hline Total & 17.5 & 21.5 & 68.1 & 1275.1 \\
\hline
\end{tabular}

Source(s): 2017 Diary of Consumer Payment Choice

Note(s): Sampling weights were applied to all statistics. 
Table 11: Regression results, payment instrument use

\begin{tabular}{|c|c|c|c|c|c|}
\hline Second Stage & Cash & Credit & & Debit & \\
\hline Demographics & $\mathrm{Y}$ & $\mathrm{Y}$ & & $\mathrm{Y}$ & \\
\hline Income & $\mathrm{Y}$ & $\mathrm{Y}$ & & $\mathrm{Y}$ & \\
\hline Total Emergency Savings & 0.00000007 & 0.00000046 & $* * *$ & -0.00000074 & $* * *$ \\
\hline Adjusted R-squared & 0.1779 & 0.2566 & & 0.1583 & \\
\hline Can cover the full $\$ 2000$ & $-0.031241 \quad * * *$ & 0.0676010 & $* * *$ & -0.07926859 & $* * *$ \\
\hline Adjusted R-squared & 0.1821 & 0.2613 & & 0.1615 & \\
\hline
\end{tabular}

Note(s): For each payment instrument, we estimate a two-stage Heckman model of payment adoption and use. Demographics, income, and relative characteristics of the instrument of interest (acceptance, cost, convenience, security, records, and setup) were included in the adoption stage. The use stage controls for demographics, income, and relative characteristics (cost, convenience, security, and records), with home ownership, setup, and acceptance as the exclusion restriction. 
Table 12: Consumer liquidity status in terms of cash holding

\begin{tabular}{l|c}
\hline & Percent or Dollar Amount \\
\hline $\begin{array}{l}\text { Used to cover part (or all) of } \$ 2,000 \text { emergency } \\
\text { expense, } \% \text { of consumers }\end{array}$ & $19 \%$ \\
\hline & $\$ 124$ \\
Mean amount from cash (whole sample) & $\$ 651$ \\
\hline $\begin{array}{l}\text { Mean amount from each source (nonzero only) } \\
\text { Mean source of fund shares, as a percentage of } \\
\text { amount payable (whole sample) }\end{array}$ & $13 \%$ \\
\hline $\begin{array}{l}\text { Mean source of fund shares, as a percentage of } \\
\text { amount payable (nonzero only) }\end{array}$ & $62 \%$ \\
\hline
\end{tabular}

Source(s): 2017 Diary of Consumer Payment Choice

Note(s): Sampling weights were applied to all statistics. 
Figure 1: Average emergency savings per person, by state

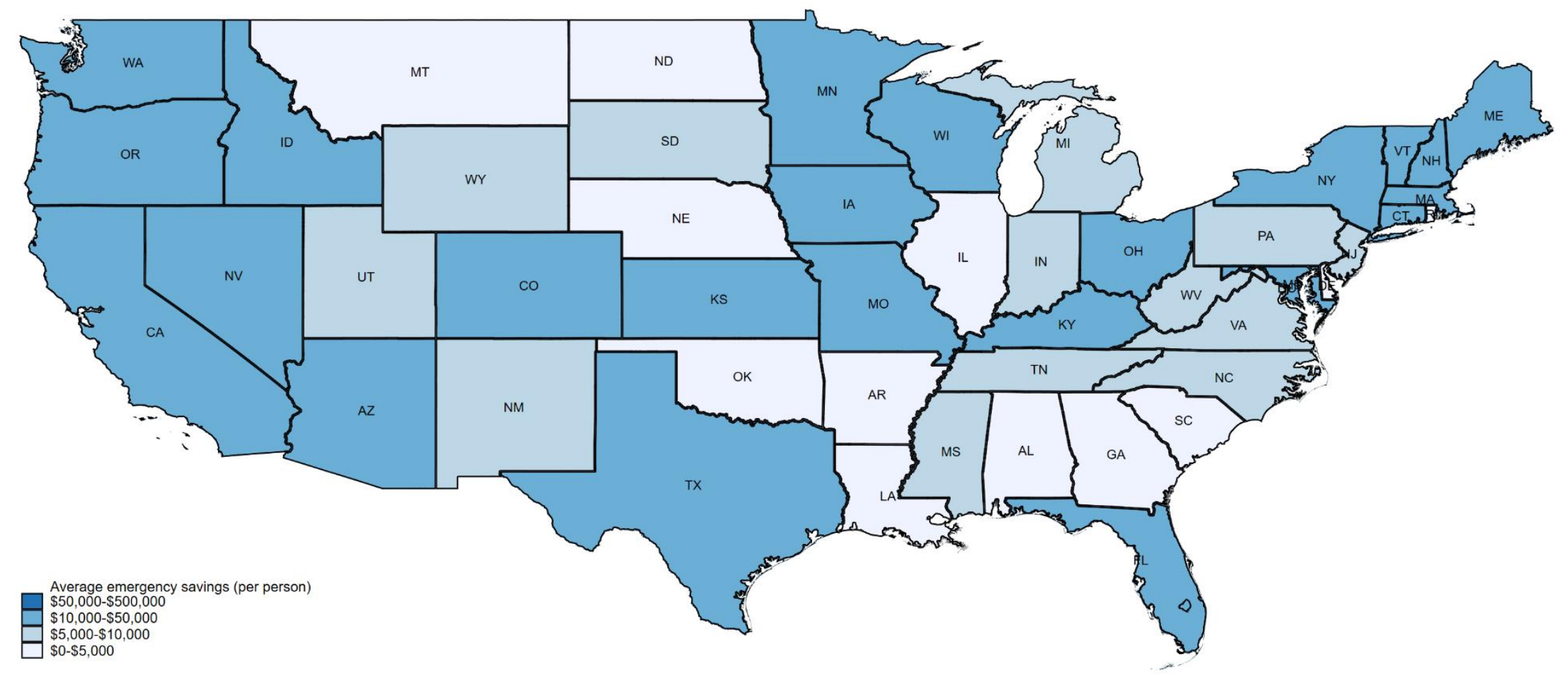

Note(s): Sample weights were applied to all statistics. The DCPC sample doesn't include consumers from American Samoa, Puerto Rico, Virgin Islands, and Guam. Source(s): 2017 DCPC 
Figure 2: Average amount covered out of $\$ 2,000$ per person, by state

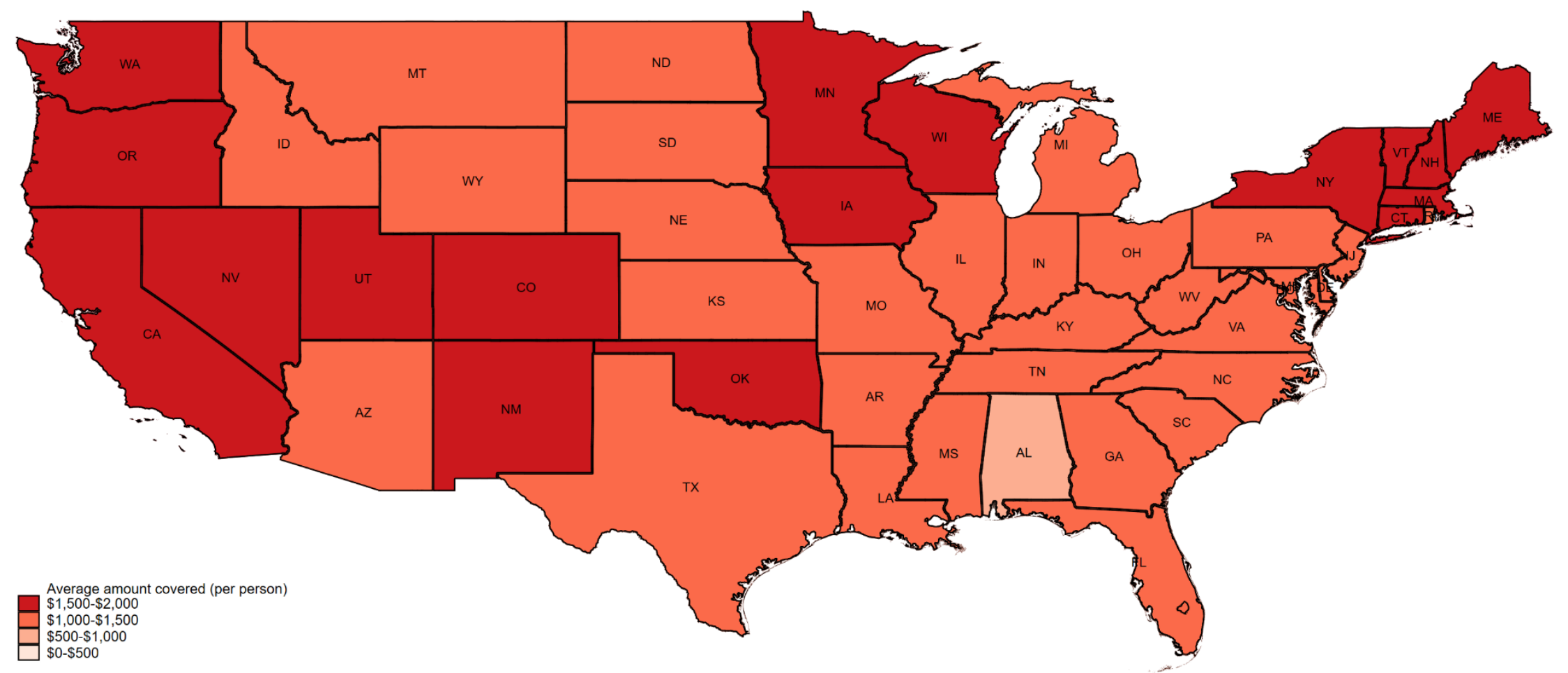

Note(s): Sample weights were applied to all statistics. The DCPC sample doesn't include consumers from American Samoa, Puerto Rico, Virgin Islands, and Guam. Source(s): 2017 DCPC 
Figure 3: Number of respondents by income cohort, unweighted count

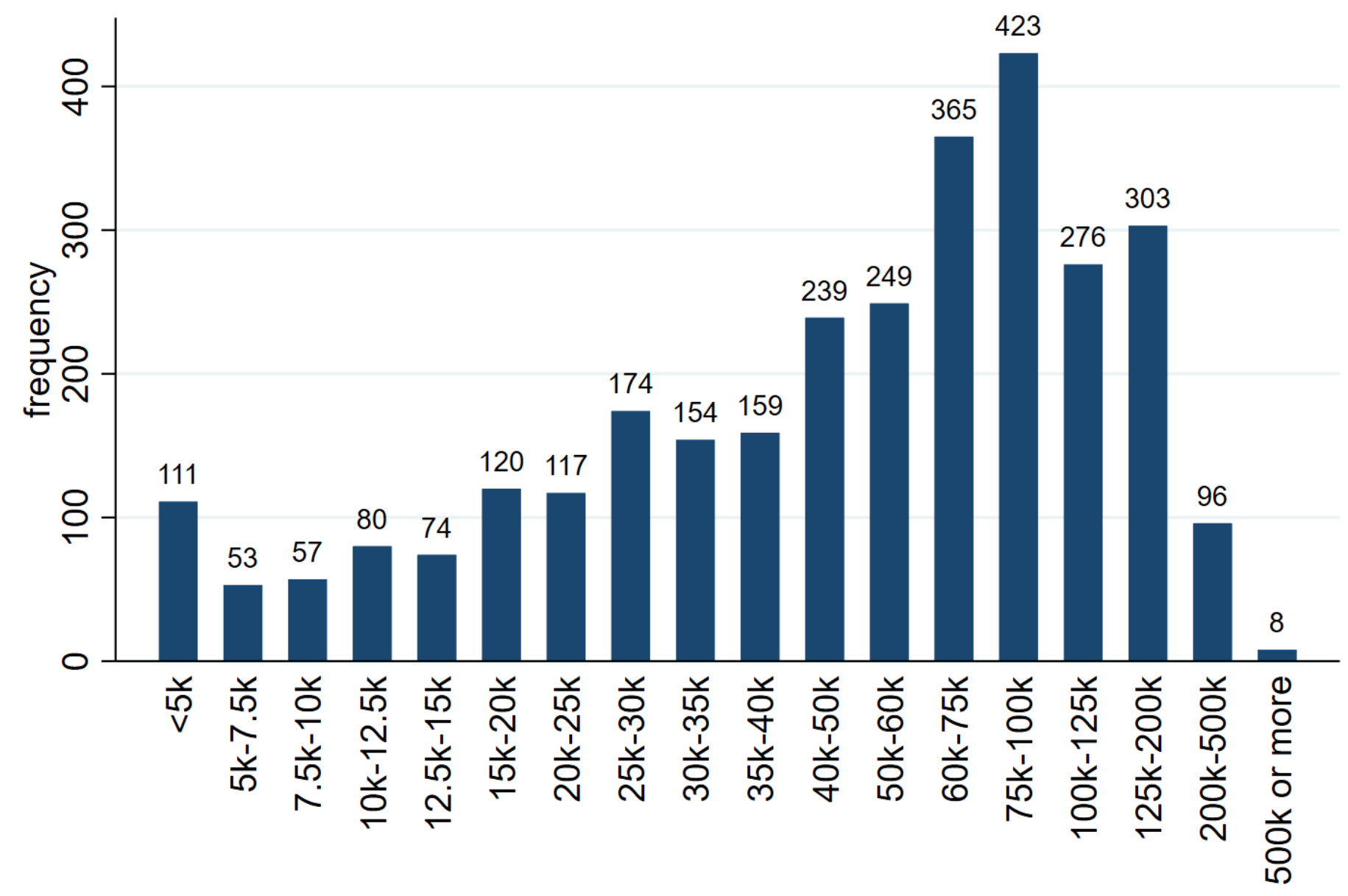

Annual Income Cohorts 
Figure 4: Number of respondents, by change in income cohorts between 2016 and 2017, unweighted count. Negative numbers indicate decrease in income, positive indicate increase in income, 0 no change. Only respondents who were in the panel in 2016 and 2017.

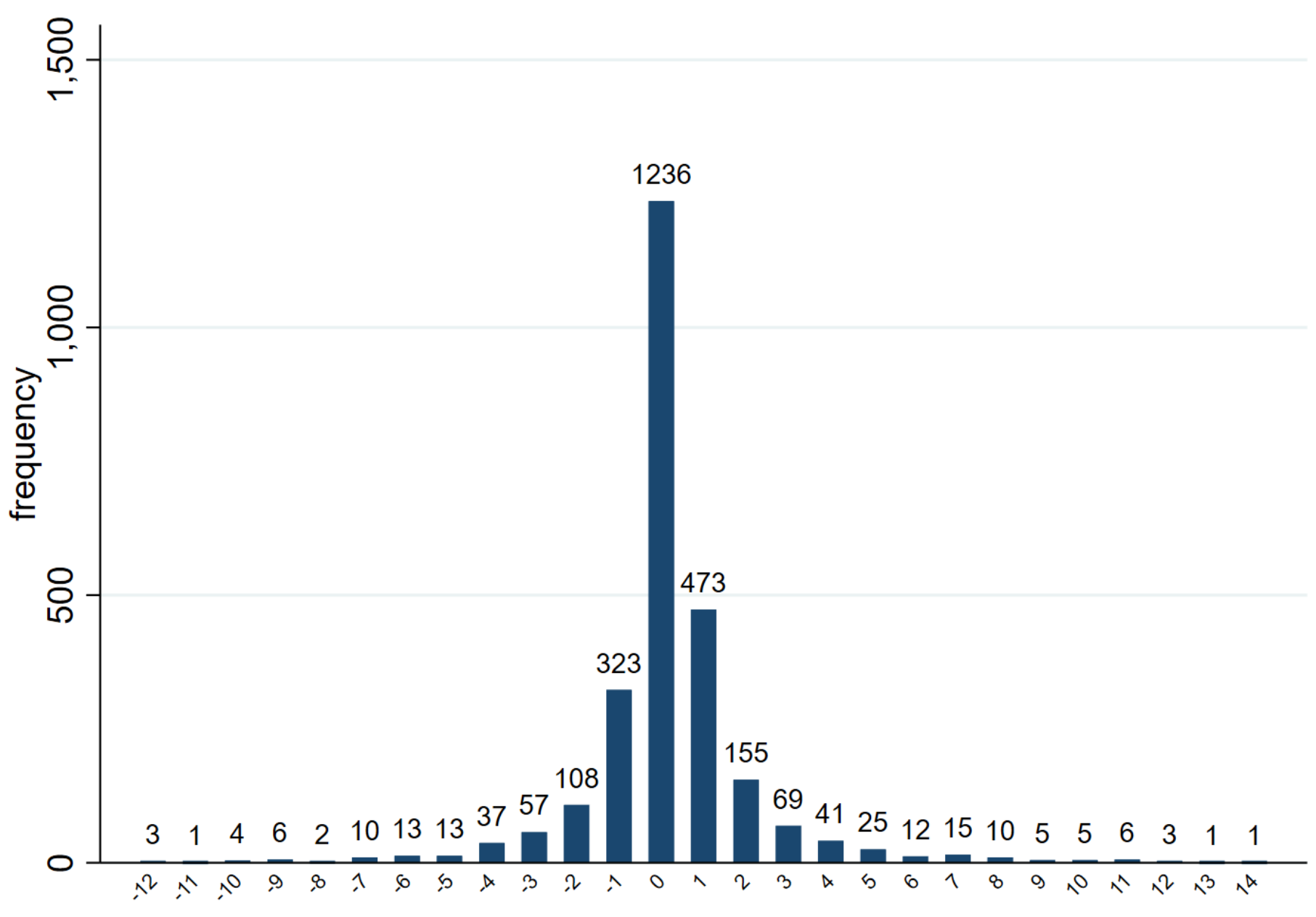

Number of Income Cohorts Decreased (-) or Increased (+) 


\section{Appendix}

In our model, adoption of a payment method is a function of various characteristics of the payment method, in addition to demographic and financial attributes of the consumer. The payment method characteristics are:

$C H A R=\{$ SECURITY, ACCEPTANCE, COST, CONVENIENCE, RECORD KEEPING, SETUP $\}$

Consumers assess each of these characteristics for each payment method. These numerical assessments are then used to construct average relative characteristics, as described below. SETUP is the difficulty of getting and setting up a payment method, and ACCEPTANCE is a measure of how widely accepted a given payment method is. Unlike the other payment method characteristics, SETUP and ACCEPTANCE affect only adoption and not use.

Characteristics are rated on a 1 through 5 scale. We are interested in consumers' rating of each payment instrument $j$ relative to all the other payment instruments $j$ '. Therefore, for each characteristic $k$, we use log relative characteristics as explanatory variables,

$$
\operatorname{RCHAR}_{k i}\left(j, j^{\prime}\right) \equiv \log \left(\frac{C H A R_{k i j}}{C H A R_{k i j^{\prime}}}\right),
$$

where $k$ indexes the characteristics security, acceptance, cost, convenience, setup, and record keeping; $i$ indexes the consumer; and $j$ is the payment instrument. In principle, all of the relative characteristics could influence a consumer's choice of any payment instrument. However, to facilitate the interpretation of the marginal effects of the characteristics on use, we construct the average relative characteristic for each payment characteristic,

$$
\overline{\operatorname{RCHAR}}_{k i}(j)=\frac{1}{J} \sum_{j^{\prime} \neq j}^{J-1} R C H A R_{k i}\left(j, j^{\prime}\right),
$$

where $J=$ all of the payment instruments. For example, $\overline{R C H A R}$ for cost in the check use equation is the average of the log ratios of the cost of the check to the cost of each of the other payment instruments. It measures how a consumer evaluates the cost of checks relative to the cost of all of the other payment methods. We expect the coefficients on all of the average relative characteristics to be positive, because a higher numerical value of $C H A R$ indicates a more 
positive assessment by a consumer, and we assume that consumers value all of the characteristics. 


\section{Appendix Tables}

Appendix Table 1: Payment use by demographics, SCPC 2017

\begin{tabular}{|c|c|c|c|c|c|c|}
\hline & & $\begin{array}{c}\text { Cash } \\
\text { \% share of all } \\
\text { payments }\end{array}$ & $\begin{array}{c}\text { Check } \\
\text { \% share of all } \\
\text { payments }\end{array}$ & $\begin{array}{c}\text { Credit } \\
\text { \% share of all } \\
\text { payments }\end{array}$ & $\begin{array}{c}\text { Debit } \\
\text { \% share of all } \\
\text { payments }\end{array}$ & $\begin{array}{c}\text { Other } \\
\% \text { share of all } \\
\text { payments }\end{array}$ \\
\hline Overall & & 28.5 & 6.1 & 21.2 & 29.3 & 14.8 \\
\hline \multirow{7}{*}{ Age } & Under 25 & 42.5 & 1.2 & 8.2 & 35.4 & 12.8 \\
\hline & $25-34$ & 27.9 & 4.1 & 20.9 & 33.1 & 14.0 \\
\hline & $35-44$ & 25.6 & 4.3 & 24.5 & 31.8 & 13.9 \\
\hline & $45-54$ & 27.2 & 5.3 & 19.6 & 31.5 & 16.5 \\
\hline & $55-64$ & 28.8 & 8.2 & 18.4 & 29.9 & 14.7 \\
\hline & Over 64 & 29.1 & 10.4 & 25.8 & 19.0 & 15.7 \\
\hline & Significantly Different? & $* * *$ & $* * *$ & $* * *$ & $* * *$ & $* *$ \\
\hline \multirow{6}{*}{ Education } & Less than high school & 50.8 & 4.6 & 5.8 & 23.6 & 15.1 \\
\hline & High school & 35.0 & 7.0 & 13.8 & 30.6 & 13.7 \\
\hline & Some college & 27.5 & 5.6 & 16.0 & 34.7 & 16.2 \\
\hline & College & 19.4 & 6.1 & 33.3 & 25.8 & 15.4 \\
\hline & Graduate & 16.6 & 6.1 & 41.3 & 22.3 & 13.7 \\
\hline & Significantly Different? & $* * *$ & $* *$ & $* * *$ & $* * *$ & $* *$ \\
\hline \multirow[t]{3}{*}{ Gender } & Male & 30.9 & 5.5 & 22.6 & 27.4 & 13.6 \\
\hline & Female & 26.3 & 6.8 & 19.9 & 31.1 & 15.9 \\
\hline & Significantly Different? & $* * *$ & $* * *$ & $* * *$ & $* * *$ & $* * *$ \\
\hline \multirow{6}{*}{ Income } & Less than 25,000 & 42.6 & 5.3 & 8.3 & 24.5 & 19.3 \\
\hline & $25,000-49,999$ & 32.8 & 6.5 & 14.5 & 31.7 & 14.4 \\
\hline & $50,000-74,999$ & 27.0 & 6.5 & 21.9 & 31.5 & 13.2 \\
\hline & $75,000-99,999$ & 22.2 & 5.9 & 23.6 & 33.8 & 14.5 \\
\hline & More than 100,000 & 19.7 & 6.1 & 34.0 & 26.6 & 13.6 \\
\hline & Significantly Different? & $* * *$ & . & $* * *$ & $* * *$ & $* * *$ \\
\hline \multirow[t]{3}{*}{ Ethnicity } & Latino & 32.8 & 3.0 & 14.2 & 37.7 & 12.2 \\
\hline & Non-Latino & 27.9 & 6.6 & 22.2 & 28.2 & 15.2 \\
\hline & Significantly Different? & $* * *$ & $* * *$ & $* * *$ & $* * *$ & $* * *$ \\
\hline \multirow{6}{*}{ Race } & White & 27.8 & 6.7 & 22.8 & 28.6 & 13.9 \\
\hline & Black & 31.5 & 4.4 & 8.5 & 35.6 & 20.1 \\
\hline & Asian & 23.9 & 4.6 & 45.8 & 14.4 & 11.3 \\
\hline & Mixed race & 31.7 & 4.3 & 16.4 & 31.6 & 16.0 \\
\hline & Other & 36.5 & 5.4 & 15.1 & 29.8 & 13.4 \\
\hline & Significantly Different? & $* * *$ & $* * *$ & $* * *$ & $* * *$ & $* * *$ \\
\hline \multirow{3}{*}{$\begin{array}{l}\text { Home } \\
\text { Ownership }\end{array}$} & Home owner & 24.4 & 7.4 & 25.3 & 28.5 & 14.5 \\
\hline & Non-home owner & 36.2 & 3.7 & 13.6 & 31.0 & 15.4 \\
\hline & Significantly Different? & $* * *$ & $* * *$ & $* * *$ & $* *$ & . \\
\hline \multirow{5}{*}{$\begin{array}{l}\text { Working } \\
\text { Status }\end{array}$} & Employed & 26.3 & 5.3 & 22.0 & 32.7 & 13.7 \\
\hline & Unemployed & 44.6 & 3.8 & 9.9 & 24.2 & 17.4 \\
\hline & Disabled or other & 33.0 & 6.5 & 15.4 & 27.6 & 17.6 \\
\hline & Retired & 27.6 & 9.9 & 28.0 & 19.2 & 15.3 \\
\hline & Significantly Different? & $* * *$ & $* * *$ & $* * *$ & $* * *$ & $* * *$ \\
\hline \multirow{4}{*}{ Residence } & Rural & 28.9 & 9.6 & 17.3 & 30.8 & 13.4 \\
\hline & Mixed cluster & 28.2 & 5.7 & 20.1 & 30.2 & 15.8 \\
\hline & Urban & 26.2 & 5.4 & 24.9 & 28.1 & 15.4 \\
\hline & Significantly Different? & . & $* * *$ & $* * *$ & . & $*$ \\
\hline
\end{tabular}

Source(s): 2017 SCPC

Note(s): Sampling weights were applied to all statistics. 
Appendix Table 2: Reliance on cash for a $\$ 2,000$ emergency expense, by income cohort

\begin{tabular}{|c|c|c|c|c|}
\hline Income Cohorts & $\begin{array}{c}\text { Consumers who rely on } \\
\text { cash for emergency } \\
\text { expense, } \\
\% \text { of total consumers } \\
\text { in this cohort }\end{array}$ & $\begin{array}{c}\text { Revolvers, } \\
\% \text { of consumers who } \\
\text { rely on cash for } \\
\text { emergency expense }\end{array}$ & $\begin{array}{l}\text { Average amount drew } \\
\text { from cash for } \\
\text { emergency use }\end{array}$ & $\begin{array}{l}\text { Average amount } \\
\text { (nonzero only) drew } \\
\text { from cash for } \\
\text { emergency use }\end{array}$ \\
\hline Less than $\$ 25,000$ & 30.0 & 41.8 & 150.5 & 502.8 \\
\hline$\$ 25,000$ - \$49,999 & 17.7 & 40.0 & 105.1 & 594.5 \\
\hline$\$ 50,000$ - $\$ 74,999$ & 19.7 & 76.4 & 153.4 & 779.8 \\
\hline$\$ 75,000$ - \$99,999 & 16.8 & 77.3 & 97.6 & 580.7 \\
\hline$\$ 100,000$ - \$124,999 & 16.7 & 62.9 & 105.7 & 631.1 \\
\hline$\$ 125,000$ - \$199,999 & 13.6 & 53.0 & 144.4 & 1058.8 \\
\hline$\$ 200,000$ and above & 3.4 & 0.0 & 30.5 & 884.1 \\
\hline Total & 19.0 & 58.6 & 123.6 & 651.3 \\
\hline
\end{tabular}

Source(s): 2017 Diary of Consumer Payment Choice

Note(s): Sampling weights were applied to all statistics. 